\title{
A THEORETICAL STUDY ON COLLAPSE MECHANISM AND STRUCTURAL BEHAVIOR OF MULTI-STORY RC FRAMES SUBJECTED TO EARTHQUAKE LOADING
}

\author{
Fayez Kaiser A., Khairy Hassan Abdelkareem, and \\ M. Abdelshakur \\ Civil Eng. Dept., Faculty of Eng., Assiut University, Assiut, Egypt
}

(Received July 21, 2008 Accepted August 31, 2008)

In the current study, nonlinear finite element approach was utilized to investigate the behavior and collapse mechanism of RC multistory frames subjected to earthquake motion. Since it is not an economic procedure to design structures to respond to earthquake loads in their elastic range, dissipation of energy by post-elastic deformation has been recommended in the last decades. Plastic hinges are specific zones at structural members where energy is dissipated through the plastic deformation without significant failure of the whole structure. This idea is an extension of the ductile design concept in building seismically resistant enoughductile and limited-ductile reinforced concrete frames. So the nonlinear behavior of multi-storey $R C$ frames under earthquake loading and the corresponding failure mechanisms were studied. The plastic hinge is assumed to occur when steel reaches yielding or concrete reaches ultimate strength. In all cases, yielding of steel occurs first because the sections are designed to be under-reinforced sections. The behavior of $R C$ multistory frames is investigated focusing on propagation of plastic hinge as affected by number of stories, grade of concrete and changing of main reinforcement ratios under the effect of three input motions. The nonlinear behavior is represented by the following items: angle of beam and column rotation; time of first beam and column hinge occurrence; total number of beam and column hinges; maximum induced base shear; peak relative horizontal acceleration; peak relative horizontal displacement; and Interstorey drift diagrams. Several conclusions are drawn out for future design of RC multistory frames.

KEYWORDS: Collapse Mechanism; Seismic Response; RC multistory Frames; Plastic Hinge Analysis; Time Integration; Nonlinear Analysis;

\section{1- INTRODUCTION}

A carefully conducted forensic engineering can reveal much insight on the nature of earthquakes and the fundamental principles of seismic design. The earthquake devastated area is sufficient proof that earthquakes release a tremendous amount of energy. This energy propagates in all directions and enters a structure as ground motion which has displacement, velocity, and acceleration components. The seismic energy which is introduced into the structure must be dissipated within the structure. Energy dissipation shows itself mainly as inelastic behavior of the structural system [1]. If seismic energy is dissipated at locations which make the structure unable to satisfy 
equilibrium of forces, collapse is inevitable. An earthquake resistant structure should dissipate seismic energy as damage in the structural system, but collapse should not occur and after the earthquake, damage should be economically feasible to repair.

Most seismic codes specify criteria for the design and construction of new structures subjected to earthquake ground motions with three goals: 1) to minimize the hazard to life for all structures; 2) to increase the expected performance of structures having a substantial public hazard due to occupancy or use; and 3) to improve the capability of essential facilities to function after an earthquake $[2,3]$. Ductility is the capacity of building materials, systems, or structures to absorb energy by deforming into the inelastic range. The capability of a structure to absorb energy, with acceptable deformations and without failure, is a very desirable characteristic in any earthquakeresistant design $[4,5]$. Concrete, a brittle material, must be properly reinforced with steel to provide the ductility necessary to resist seismic forces [6].

Many parameters may share with different degrees in forming the overall seismic behavior of a frame structure [7]. In this study, we will deal with the effect of changing of number of stories, grade of concrete and percentage of beam reinforcement (\% As beam $)$ and the percentage of column reinforcement $\left(\% \mathrm{As}_{\mathrm{col}}\right)$ on RC frames non-linear seismic response through employing the Fast Non-linear Analysis technique (FNA) [8].

Since the behavior of plastic zones in reinforced concrete elements- such as beams, columns and walls- is a sophisticated subject, many researchers aimed to find the different parameters that control their occurrence and mechanisms of their succession in multi - storey, multi - bay frames [9],[10],[11] . The following parameters greatly influence plastic zones behavior:-

1- Main flexural reinforcement;

2- Compression reinforcement;

3- Cross- section dimensions;

4- Compressive strength;.

5- Lateral confinement;

6- Number of stories;

7- Grade of concrete and

8- Method of load application.

Dealing with the plastic hinge problem alone is clear a little bit especially under static and quasi - static loading [12], while using varying loads through time domain such that earthquake loading is a difficult subject and consumes a lot of time $[13,14]$. In order to get a good idea of non-linear response of the multi-storey multibay reinforced concrete frames under seismic loading, we used three significant 60second records of Al-Aqaba, El-Centro, and Lucerne earthquake motions. To enclose the different aspects that may affect the non-linear seismic response, the following features were adopted:

1- Angle of beam and column rotation;

2- Time of first beam and column hinge occurrence;

3- Total number of beam and column hinges;

4- Maximum induced base shear;

5- Peak relative horizontal acceleration;

6- Peak relative horizontal displacement; and

7- Inter-storey drift diagrams. 


\section{2-STRUCTURAL DESCRIPTION AND PARAMETERS OF STUDY}

- Dimensions: Two cases of planer frames with two different numbers of stories which are five and ten stories were examined where both have three bays with fixed bay width of 5 meters, fixed typical height of 3 meters and a first storey height of 4 meters as shown in Fig.1.

- Concrete and steel characteristics: Variable grades of concrete (cube strength) $(200,400$ and 600$) \mathrm{kg} / \mathrm{cm} 2$ are used while steel grade is $36 / 52$. Concrete and steel Poisson's ratios were taken as $0.2 \& 0.3$ respectively [15].

- Main reinforcement ratio (As/b.d): In both cases, we will use different percentages of reinforcement in the beam and column where;

The beams (As) is the area of longitudinal reinforcement in the tension side of the beam while ( $b$ and $d)$ are the breadth and the effective depth of the beam respectively. Different ratios of $(\mathrm{As} / \mathrm{b} . \mathrm{d})=0.34 \%, 0.53 \%$ and $0.76 \%$ were used.

The columns (As) is the total area of reinforcement in the section of the frame while (b and d) are the breadth and the effective depth of the column respectively. In this study, we use different ratios of $(\mathrm{As} / \mathrm{b} . \mathrm{d})=2.83 \%, 2.15 \%$ and $1.11 \%$.

- Loading: A uniformly distributed vertical load of $3.8 \mathrm{t} / \mathrm{m}$ ' on every story was used for both cases representing a combination of full dead load plus $50 \%$ of live load as stated in many building codes.

Table 1 : Different parameters controlling the cases of study

\begin{tabular}{|c|c|c|c|c|c|c|c|c|}
\hline $\begin{array}{c}\text { Study } \\
\text { parameters }\end{array}$ & $\begin{array}{c}\text { Frame } \\
\text { no.1 }\end{array}$ & $\begin{array}{c}\text { Frame } \\
\text { no.2 }\end{array}$ & $\begin{array}{c}\text { Frame } \\
\text { no.3 }\end{array}$ & $\begin{array}{c}\text { Frame } \\
\text { no.4 }\end{array}$ & $\begin{array}{c}\text { Frame } \\
\text { no.5 }\end{array}$ & $\begin{array}{c}\text { Frame } \\
\text { no.6 }\end{array}$ & $\begin{array}{c}\text { Frame } \\
\text { no.7 }\end{array}$ & $\begin{array}{c}\text { Frame } \\
\text { no.8 }\end{array}$ \\
\hline $\begin{array}{c}\text { Grade of } \\
\text { concrete } \\
\mathrm{kg} / \mathrm{cm} 2\end{array}$ & 200 & 200 & 200 & 200 & 200 & $\begin{array}{c}400 / 400 \\
\mathrm{c} / \mathrm{b}\end{array}$ & $\begin{array}{c}400 / 600 \\
\mathrm{c} / \mathrm{b}\end{array}$ & $\begin{array}{c}400 / 200 \\
\mathrm{c} / \mathrm{b}\end{array}$ \\
\hline $\begin{array}{c}\% \text { As of } \\
\text { beams } \\
(36 / 52)\end{array}$ & $\begin{array}{c}0.34 \\
\%\end{array}$ & $\begin{array}{c}0.53 \\
\%\end{array}$ & $\begin{array}{c}0.76 \\
\%\end{array}$ & $\begin{array}{c}0.53 \\
\%\end{array}$ & $\begin{array}{c}0.53 \\
\%\end{array}$ & $0.53 \%$ & $0.53 \%$ & $0.53 \%$ \\
\hline $\begin{array}{c}\% \text { As of } \\
\text { col. } \\
(36 / 52)\end{array}$ & $\begin{array}{c}1.11 \\
\%\end{array}$ & $\begin{array}{c}1.11 \\
\%\end{array}$ & $\begin{array}{c}1.11 \\
\%\end{array}$ & $\begin{array}{c}2.15 \\
\%\end{array}$ & $\begin{array}{c}2.83 \\
\%\end{array}$ & $1.11 \%$ & $1.11 \%$ & $1.11 \%$ \\
\hline Stirrups & \multicolumn{70}{|c|}{$6 \Phi 10 / \mathrm{m}(36 / 52)$} \\
\hline
\end{tabular}

Table 2 : Cross-sections of frame members

\begin{tabular}{|c|c|c|c|c|c|}
\hline & $\begin{array}{c}5 \text {-storey } \\
\text { frame }\end{array}$ & \multicolumn{4}{|c|}{10 -storey frame } \\
\hline Floor No. & $1^{\text {st }}-5^{\text {th }}$ & Grd $-1^{\text {st }}$ & $r^{\text {nd }}-3^{\text {rd }}$ & $4^{\text {th }}-5^{\text {th }}$ & $6^{\text {th }}-10^{\text {th }}$ \\
\hline Beam cross-sections & $25 \times 60$ & \multicolumn{4}{|c|}{$25 \times 60$} \\
\hline $\begin{array}{c}\text { Column cross- } \\
\text { sections }\end{array}$ & $30 \times 60$ & $30 \times 90$ & $30 \times 80$ & $30 \times 70$ & $30 \times 60$ \\
\hline
\end{tabular}




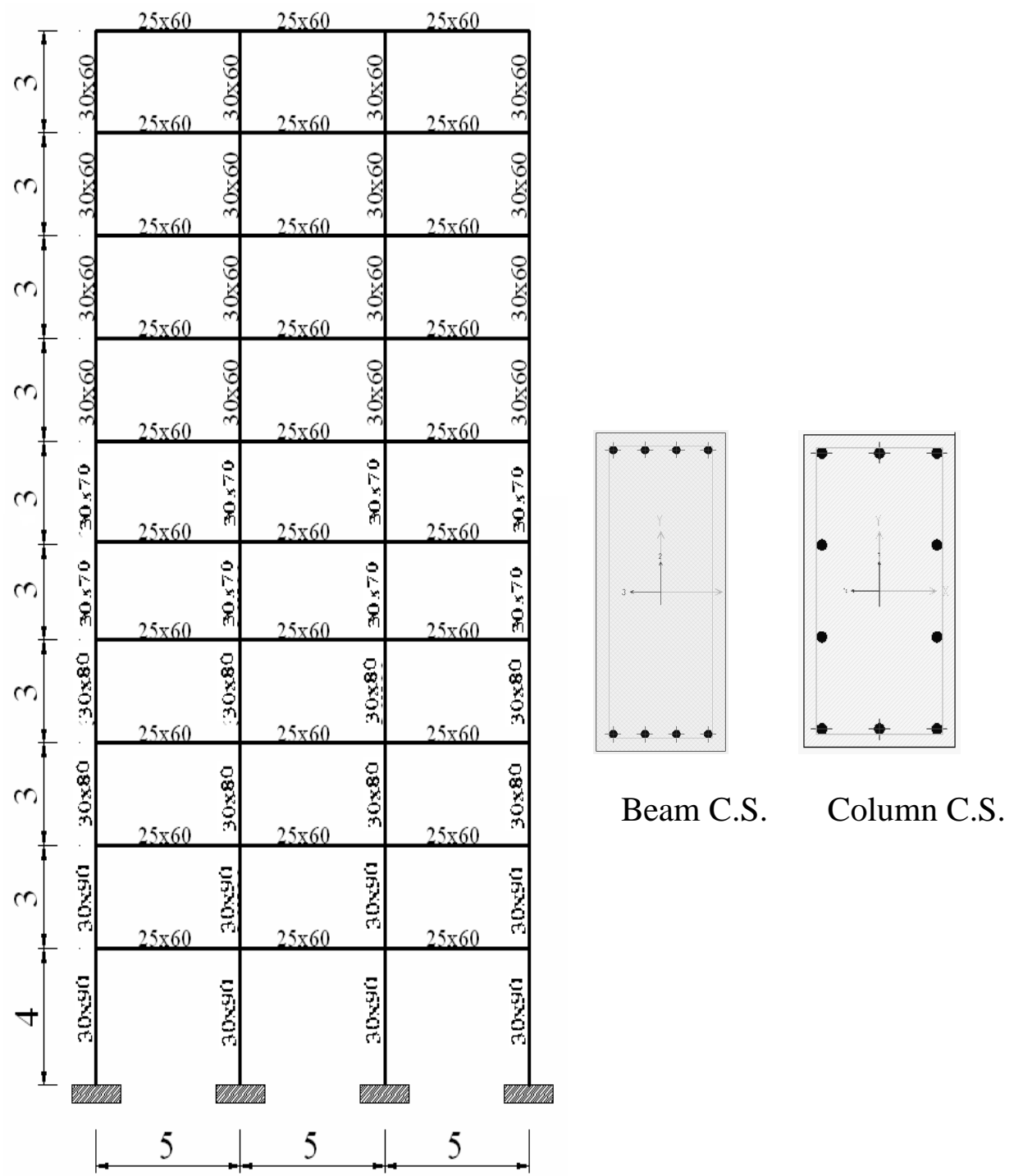

Fig,1: Frame dimensions and members cross-sections

\section{3- PLASTIC HINGE AND MATERIAL MODELING Constitutive concrete Model by Chang and Mander (1994)}

The uniaxial model developed by Chang and Mander was adopted in the present study as the basis for the stress-strain relation for concrete as illustrated in Fig.2. The constitutive model by Chang and Mander is an advanced, rule-based, generalized, and non-dimensional model that simulates the behavior of confined and unconfined, ordinary and high-strength concrete in both cyclic compression and tension $[16,17$, 18]. Upon development of the model, the authors focused particular emphasis on the 
transition of the stress-strain relation upon crack opening and closure, which had not been adequately addressed in previous models. Most existing models (including the model by Yassin (1994)) assume sudden crack closure with rapid change in section modulus (i.e., sudden pinching behavior).

\section{Constitutive steel modified Model by Park (1982)}

The uniaxial constitutive stress-strain relation implemented in the study for reinforcing steel is the well-known nonlinear modified model of Park (1982), as extended by Filippou et al. (1983) to include isotropic strain hardening effects. The model is computationally efficient and capable of reproducing experimental results with accuracy.

$$
\begin{aligned}
& \mathrm{r}=\varepsilon_{\mathrm{su}}-\varepsilon_{\mathrm{sh}} \\
& \mathrm{m}=\left[\left(\mathrm{f}_{\mathrm{su}} / \mathrm{f}_{\mathrm{sy}}\right)(30 \mathrm{r}+1)^{2}-60 \mathrm{r}-1\right] /\left(15 \mathrm{r}^{2}\right) \\
& \left.\mathrm{f}_{\mathrm{s}}=\mathrm{f}_{\mathrm{sy}}\left[\left(\mathrm{m}\left(\varepsilon_{\mathrm{s}}-\varepsilon_{\mathrm{sh}}\right)+2\right) /\left(60 \varepsilon_{\mathrm{s}}-\varepsilon_{\mathrm{sh}}\right)+2\right)+\left(\left(\varepsilon_{\mathrm{s}}-\varepsilon_{\mathrm{sh}}\right)(60-\mathrm{m})\right) /\left(2(30 \mathrm{r}+1)^{2}\right)\right]
\end{aligned}
$$

Where: $\varepsilon_{\mathrm{su}}=$ ultimate strain capacity of steel.

$\varepsilon_{\mathrm{sh}}=$ strain in steel at onset of strain hardening.

$\mathrm{f}_{\mathrm{su}}=$ ultimate stress capacity of steel.

$\mathrm{f}_{\mathrm{sy}}=$ yield stress of steel .

$\varepsilon_{\mathrm{sy}}=$ yield strain of steel.

$\mathrm{f}_{\mathrm{s}}=$ stress of steel at any point .
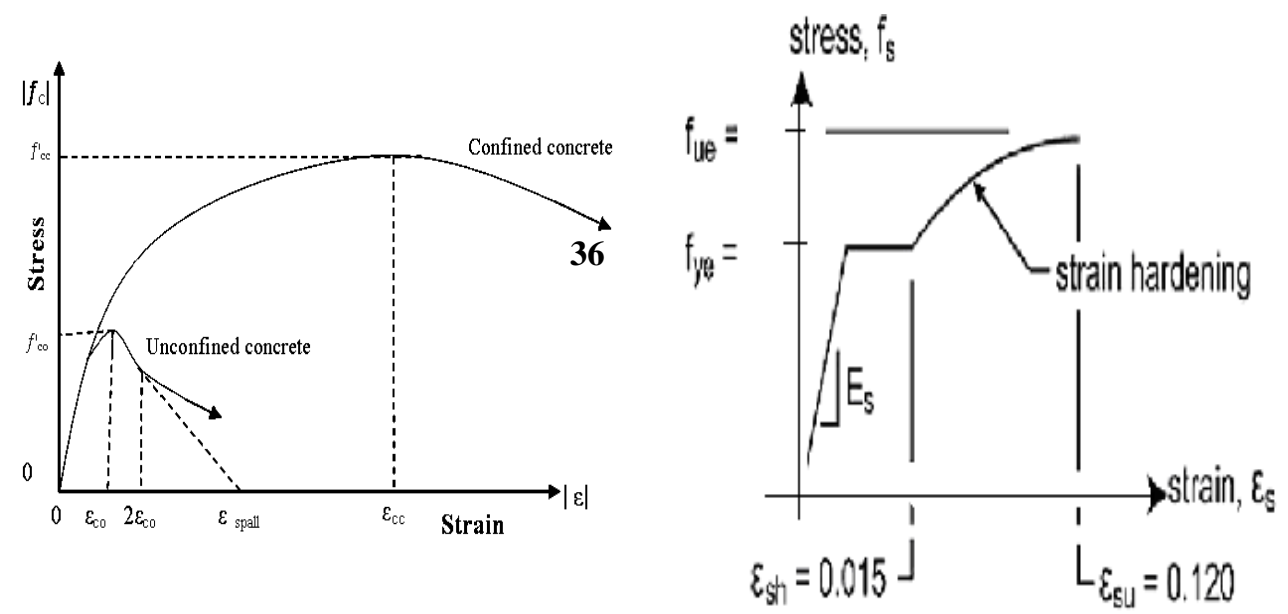

Fig. 2: Sketch illustrating concrete $\&$ steel stress-strain relationship 
To take into account the concrete degradations when subjected to many cycles of load reversals, the nonlinear hinges are made capable of representing the degradation model developed by Takeda. According to this Model, the stiffness of the element is reduced every time the element experiences a load reversal. This Model is based on the experimental observation on the behavior of a number of medium-size reinforced concrete members tested under lateral load reversals with light to medium amount of axial load; a hysteresis model was developed by Takeda, Sozen and Nielsen (1970). Takeda model included (a) stiffness changes at flexural cracking and yielding, (b) hysteresis rules for inner hysteresis loops inside the outer loop, and (c) unloading stiffness degradation with deformation. The response point moves toward a peak of the one outer hysteresis loop (see Fig.3).
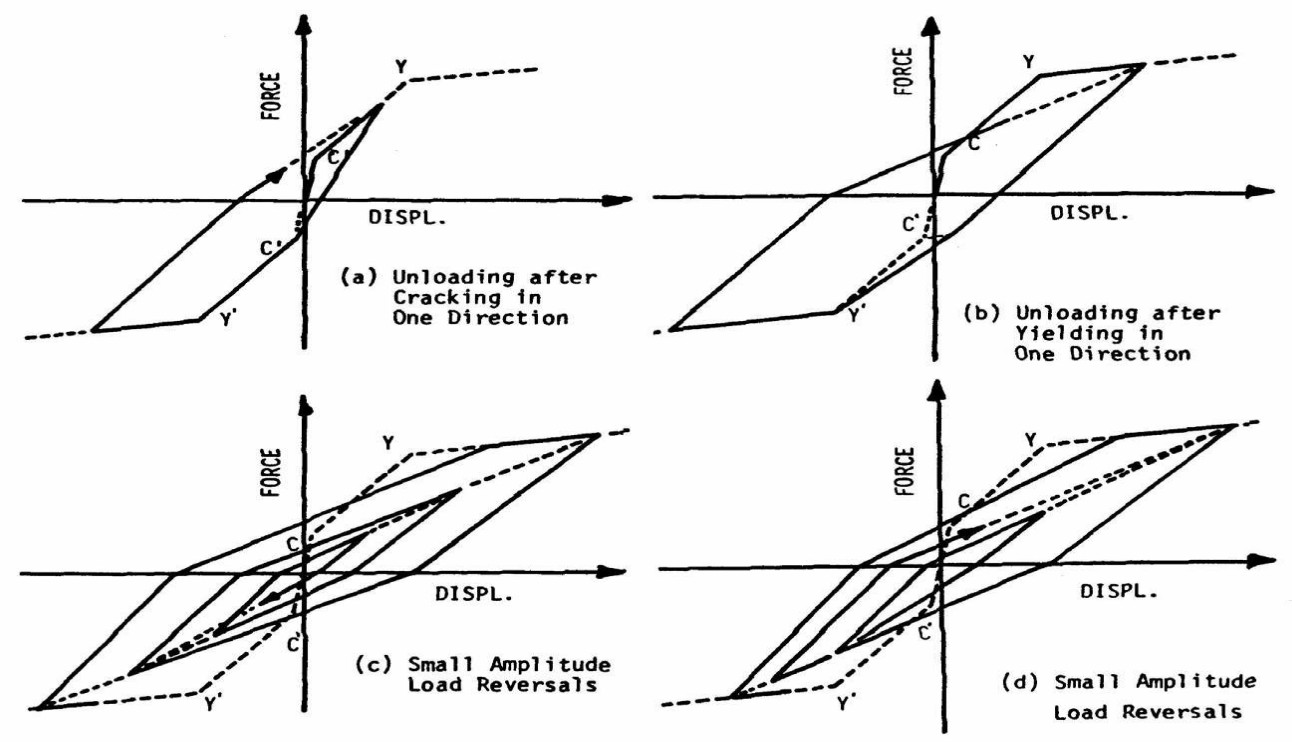

Fig. 3: Takeda hysteretic model

\section{4-METHOD OF STRUCTURAL ANALYSIS}

Dealing with seismic problems, we can recognize four different methods for structural analysis as mentioned in (ATC-40 (1996), FEMA-350 (2000) and FEMA- 356 (2000) [19].

1. Linear Static procedure (LSP).

2. Linear dynamic procedure (LDP) or (response spectrum analysis).

3. Nonlinear static procedure (NSP) or (pushover analysis).

4. Nonlinear dynamic procedures (NDP).

The NDP refers to a complete nonlinear dynamic time history analysis and is generally regarded as the most accurate method also the most time consuming one. The most general approach for the solution of the dynamic response of structural systems is the direct numerical integration of the dynamic equilibrium equations. The method employed for the solution is New-Mark time integration method (including an improved algorithm called "Hilber-Hughes-Taylor alpha" (HHT) method). The NewMark method and HHT method are available for transient analyses in SAP v.11 and 
CSISD programs where both were used in this study [20]. In a nonlinear analysis, the Newton-Raphson method is employed along with the New-Mark integration assumptions. Automatic Time Stepping discusses the procedure for the program to automatically determine the time step size required for every time step. In transient analysis, the HHT time integration method (Chung and Hulbert) has the desired property for the numerical damping. The basic equation of motion solved by a transient dynamic analysis is

$$
\text { (M) }\left\{\mathrm{u}{ }_{\mathrm{t}}\right\}+(\mathrm{C})\left\{\mathrm{u}_{\mathrm{t}}\right\}+(\mathrm{K})\left\{\mathrm{u}_{\mathrm{t}}\right\}=\left\{\mathrm{F}_{\mathrm{t}}\right\}
$$

Where: $\quad(\mathrm{M})=$ mass matrix.

(C) $=$ damping matrix.

$(\mathrm{K})=$ stiffness matrix

$\left\{u^{\prime \prime}{ }_{t}\right\}=$ nodal acceleration vector.

$\left\{u_{t}\right\}=$ nodal velocity vector.

$\left\{\mathrm{u}_{\mathrm{t}}\right\}=$ nodal displacement vector.

$\left\{\mathrm{F}_{\mathrm{t}}\right\}=$ load vector.

The basic form of the HHT method is given by

$$
\begin{aligned}
(\mathrm{M})\left\{\mathrm{u}_{\mathrm{t}}{ }_{\mathrm{t}}\right\}+(1+\alpha)(\mathrm{C})\left\{\mathrm{u}_{\mathrm{t}}\right\}+(1+\alpha)(\mathrm{K})\left\{\mathrm{u}_{\mathrm{t}}\right\}= \\
(1+\alpha)\left\{\mathrm{F}_{\mathrm{t}}\right\}-\alpha\left\{\mathrm{F}_{\mathrm{t}}\right\}+\alpha(\mathrm{C})\left\{\mathrm{u}_{\mathrm{t}-\Delta \mathrm{t}}\right\}+\alpha(\mathrm{K})\left\{\mathrm{u}_{\mathrm{t}-\Delta \mathrm{t}}\right\}
\end{aligned}
$$

For nonlinear analysis of a reinforced concrete structure, using $\alpha$ with values greater than zero assists in convergence of the solutions but with less accuracy, to gain better accuracy use smaller sub-step size, which will increase computer computational time. In dynamic analysis, there are two distinct types of damping: Modal damping and proportional damping. The former is used for response-spectrum analyses and for modal time-history analyses and is given as a fraction of critical damping for each mode in the structure. While proportional damping is used for direct-integration timehistory analysis so it was adopted in this study [20]. The damping matrix is calculated as a linear combination of the stiffness matrix scaled by a user-specified coefficient, and the mass matrix scaled by a second user-specified coefficient. The two coefficients were computed by specifying equivalent fractions of critical modal damping at two different periods or frequencies. Stiffness proportional damping is linearly proportional to frequency; mass proportional damping is linearly proportional to period.

In this study a mass proportional coefficient of 0.5402 and 0.2571 with a stiffness proportional coefficient of 0.00332 and 0.007237 were used for the 5-storey and 10-storey frames respectively. These coefficients were calculated using the periods of the first two modes of vibration (0.8905 - 0.2726) and (1.8401- 0.604) for 5-story and 10-story frames respectively assuming damping ratio of $5 \%$ for both cases.

\section{5-SEISMIC LOADING DATA}

When creating the time history function for the analysis, one must provide the file containing the acceleration record. Once the file is uploaded to the program, usually as a text file, specify number of header lines to skip, prefix characters to skip, points per line and the values of the time intervals, in this study we use a detailed time history of 
3000 time step at .02 second time interval with nonlinear solution control parameters included in table 3.

Table 3 : Nonlinear solution control parameters

\begin{tabular}{|c|c|}
\hline Max. sub-step size & $0.0025 \mathrm{sec}$ \\
\hline Min. sub-step size & $0.0000001 \mathrm{sec}$ \\
\hline Max. iterations per sub-step & 100 \\
\hline Iterations convergence tolerance & $1 \%$ \\
\hline
\end{tabular}

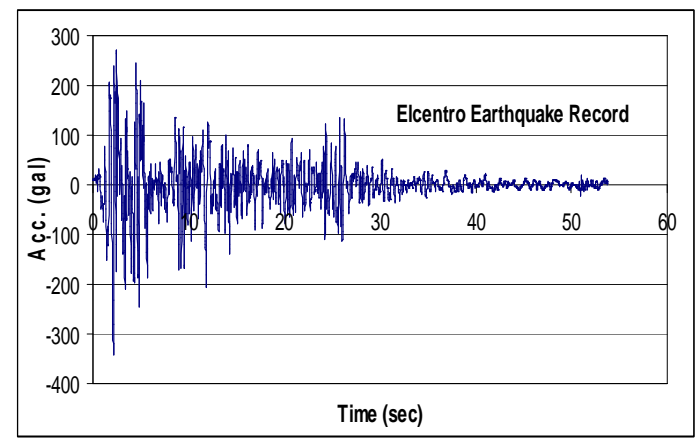

Fig.4: Input time history with PGA of $3.42 \mathrm{~m} / \mathrm{s}^{2}$

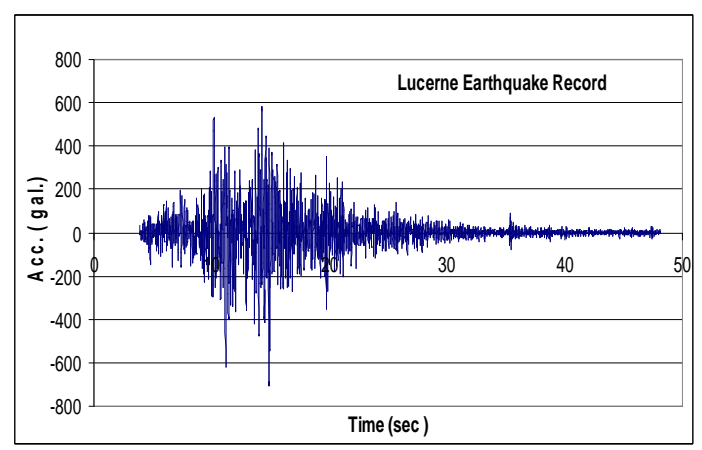

The time histories used in this study are of real significant earthquakes that strike three different cities with various site conditions and peak ground accelerations (PGA) as shown in Fig.4, 5 and 6 they where used after scaling their (PGA) to $0.25 \mathrm{~g}$ which meet the egyptian peak ground acceleration used in calculating the elastic horizontal response spectrum according to the egyptian code of calculating forces and loads (see Fig. 7). Al-Aqaba earthquake is the nearest and most destructive seismic wave that hits Egypt in November 1995 with the highest modified Mercalli intensity (MMI )of VIII at Nuweiba, El-Centro earthquake that hits California in 1940 with PGA of $0.35 \mathrm{~g}$ and above VII on ( MMI scale ) and Lucerne one of the biggest events in Switzerland and Europe with PGA of $0.7 \mathrm{~g}$.

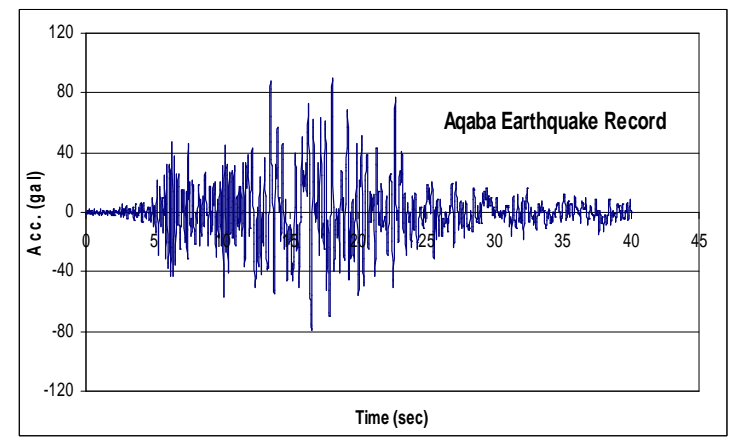

Fig.6: Input time history with PGA of $0.9 \mathrm{~m} / \mathrm{s}^{2}$

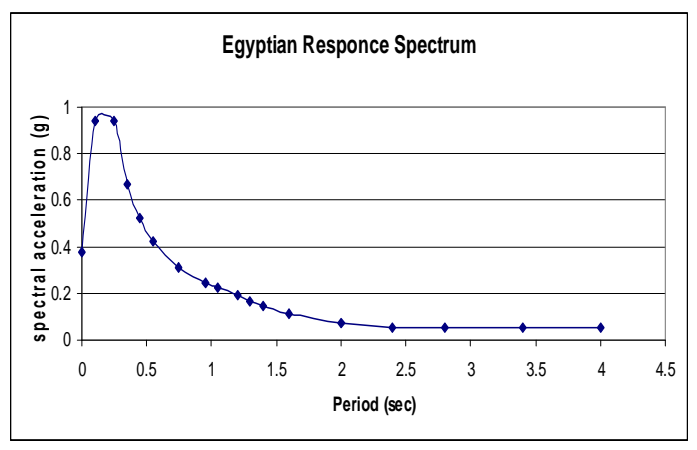

Fig .7: Egyptian elastic response spectrum 


\section{6- NONLINEAR RESPONSE UNDER EARTHQUAKE EXCITATION}

\section{First case: Five story R.C. frame}

-Beam longitudinal reinforcement effect: Plastic hinge rotation helps in nonlinear response judgment process as it reflects the degree of damage in structural members. The rotational angles of plastic hinges were calculated using their plastic curvatures and plastic hinge length excluding their elastic rotations [21]. The results show that the angle of plastic rotation is directly affected by the ratio of longitudinal reinforcement where on increasing $\% \mathrm{As}_{\text {beam }}$ with $120 \%$ the rotation is decreased with ratios varying from $50 \%$ to $100 \%$ according to the seismic wave nature as in Fig. 9. It should be mentioned that the time of first beam hinge was not increased significantly with increasing the $\% \mathrm{As}_{\text {beam }}$, also the peak horizontal displacement of the fifth floor did not show clear increase even if the \%As beam was duplicated as given in Fig. 8 and 11.

One of the most significant effects of increasing the longitudinal reinforcement ratio of beams is the total number of plastic hinges whish are formed at the beam ends; where on duplicating the percentage of beam reinforcement the occurrence of beam plastic hinges directly responds to this increase with decreasing ratios varying from $60 \%$ till 100\% approximately as shown in Fig. 12. Also on taking the plastic hinges formed at column ends into consideration through the ratio of beam plastic hinge number to column plastic hinge number at different earthquake excitations, it was found that this ratio is decreased greatly by increasing the $\% \mathrm{As}_{\text {beam }}$ as seen in Fig.10 . 


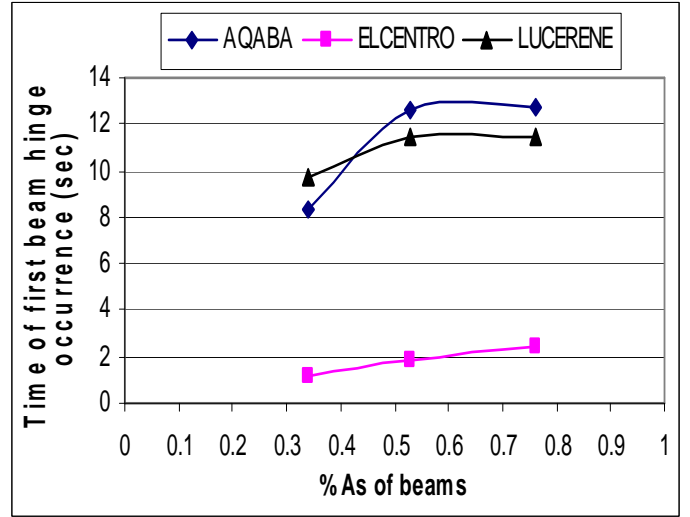

Fig.8: First beam hinge time of occurrence

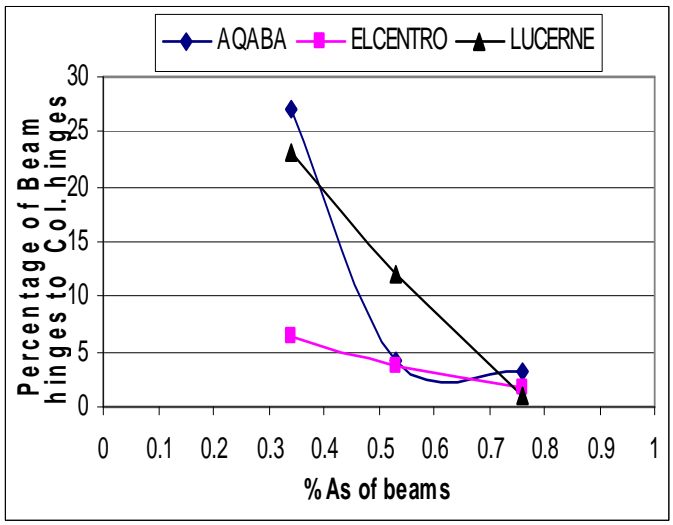

Fig.10: Percentage of beam hinge to col.

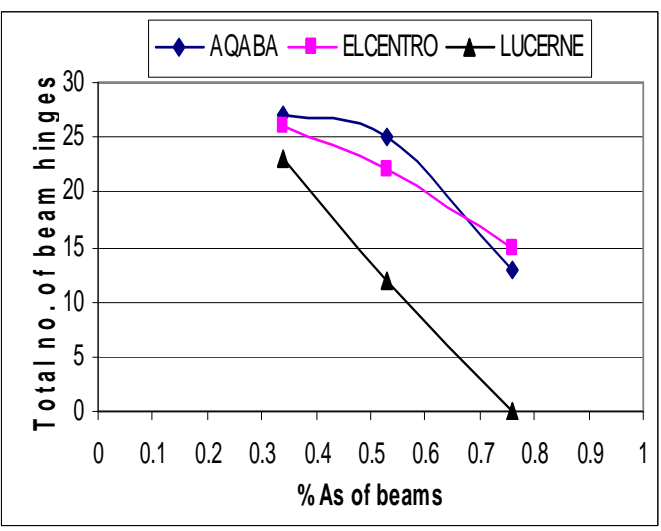

Fig.12: Total number of beam hinges

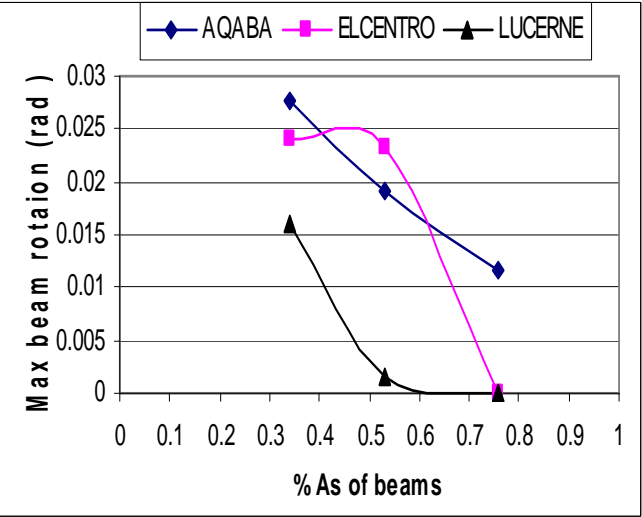

Fig.9: Max. beam hinge rotation

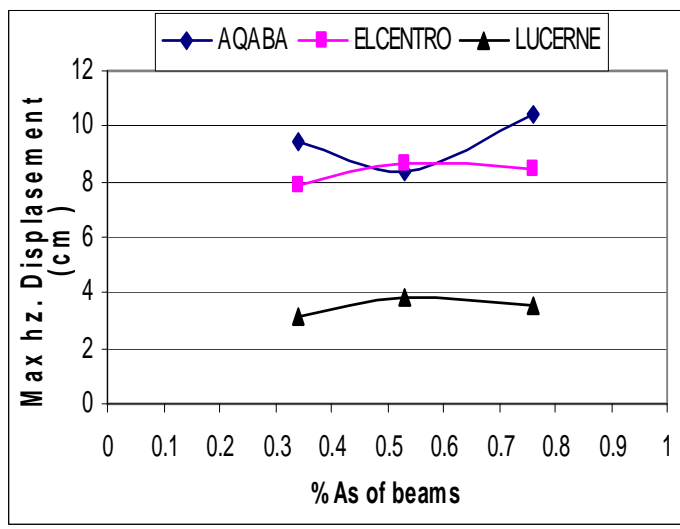

Fig.11: Max. Horizontal displacement

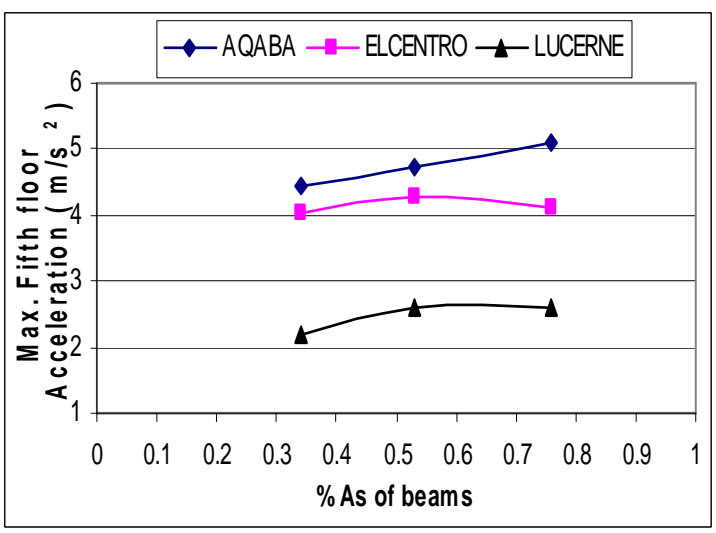

Fig.13: Max. $5^{\text {th }}$ floor acceleration 
Since the damage study isn't restricted only to structural members but also to equipments placed on the floors and non-structural partitions, so it is required to study the floor peak accelerations and the inter-storey drifts. It is noticed that on increasing the $\%$ As beam to about $120 \%$ the peak floor acceleration shows slight increase as in Fig.13. After calculating and plotting inter-storey drifts from every floor displacement at the moment of peak fifth floor displacement it did not show any significant relation with varying $\%$ As beam except for \% As beam of $0.34 \%$ that keep constant drifts especially after raising the strength of ground columns to overcome high drifts of first stories as shown in Figs. 14, 15 and 16.

The maximum induced base shear of the frame was also noticed. On increasing the $\% \mathrm{As}_{\text {beam }}$ with $120 \%$ to reach $0.76 \%$ of beam cross-section, the maximum base shear was only increased with 20\% - 25\% as shown in Fig. 17.

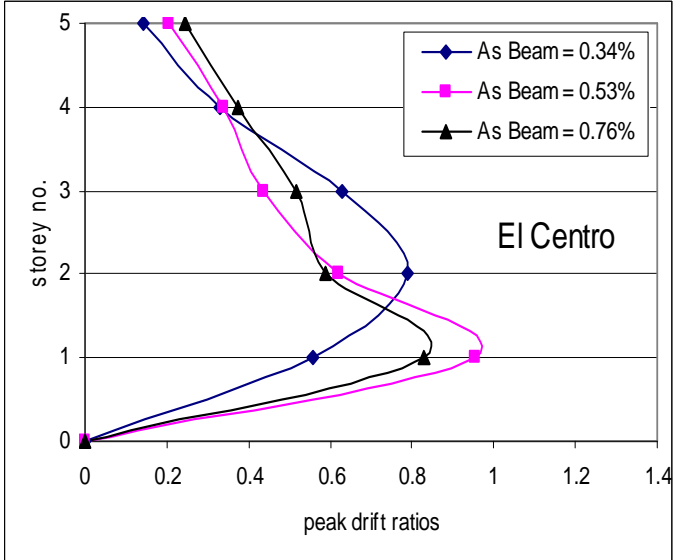

Fig.14: Inter-story drifts due to El-Centro

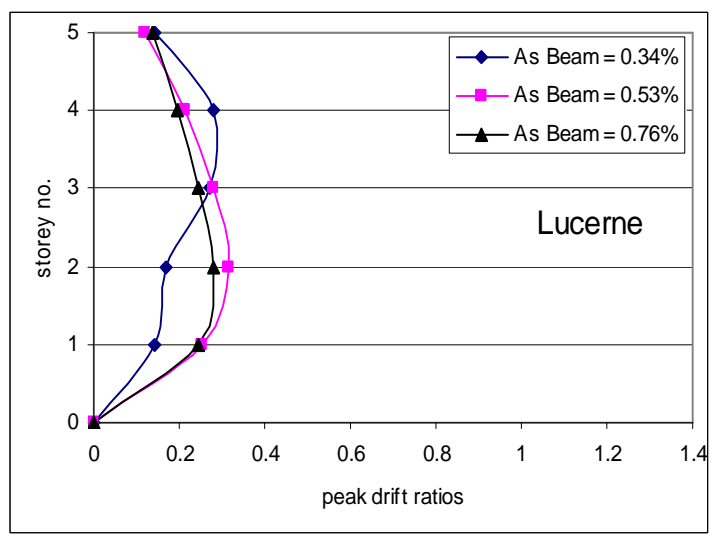

Fig.16: Inter-story drifts due to Lucerne

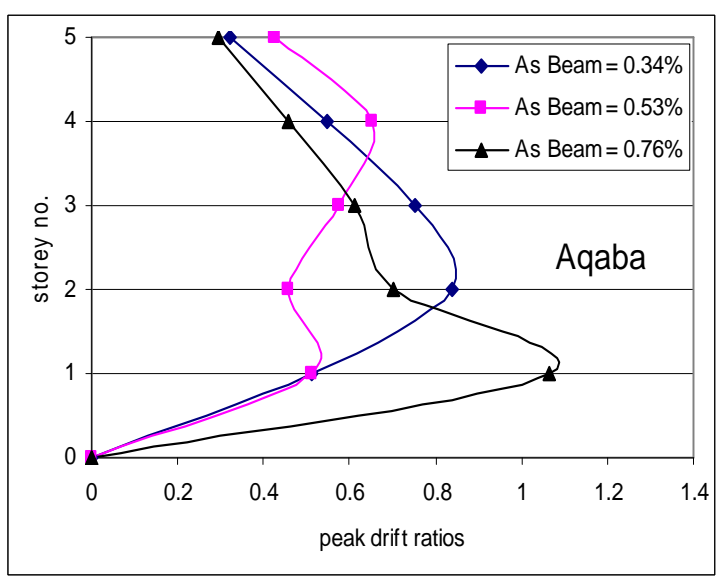

Fig.15: Inter-story drifts due to Al-Aqaba

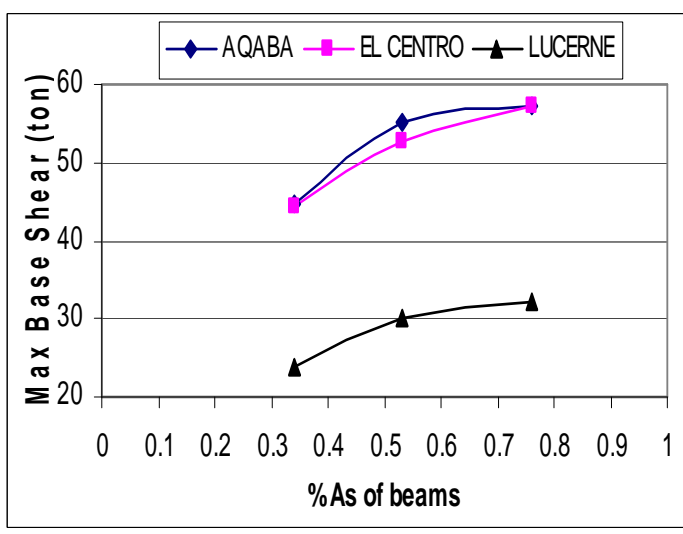

Fig.17: Max. induced base shear 
- Column longitudinal reinforcement effect: As mentioned above, the plastic hinge rotation is a useful comparison tool of nonlinear behavior. The rotational angles of column plastic hinges were calculated using moment-normal forces interaction curves to take in consideration the corresponding normal force. The results show that the angle of plastic rotation is affected by the column longitudinal reinforcement ratio in different manners as seen in Fig.18, where on increasing \% As col with 150\% the column rotation vanishes and on increasing $\% \mathrm{As}_{\mathrm{col}}$ with $100 \%$ the column rotation decreased with different ratios according to nature of the seismic wave. It should be mentioned that plastic rotations of beams was also influenced with increasing $\% \mathrm{As}_{\text {col }}$, where it shows an increase with about $30 \%-60 \%$ on increasing $\% \mathrm{As}_{\text {col }}$ by $150 \%$ as shown in Fig. 19. The same as in beams the time of first column hinge did not increase significantly with increasing their longitudinal reinforcement ratios as illustrated in Fig.23, also the peak horizontal displacement of the $5^{\text {th }}$ floor was not affected by $\%$ As col

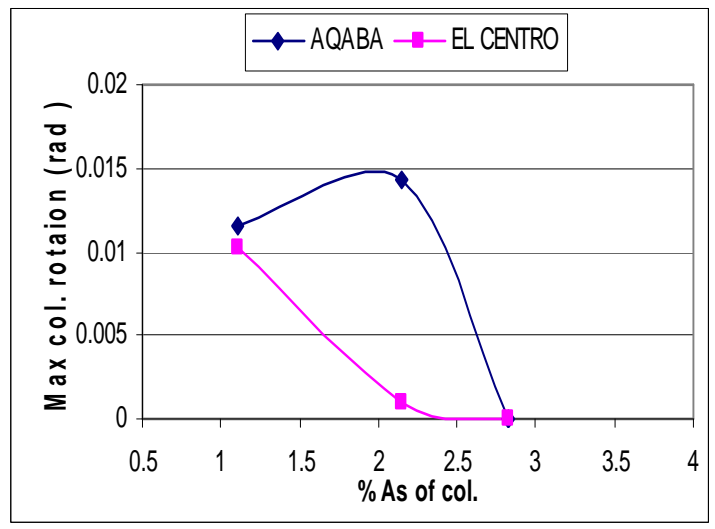

Fig.18: Max. Column hinge rotation

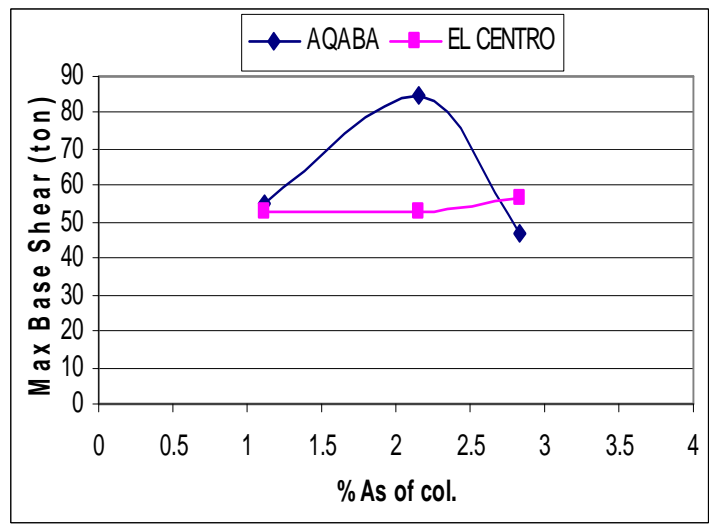

Fig.20: Max. Induced base shear

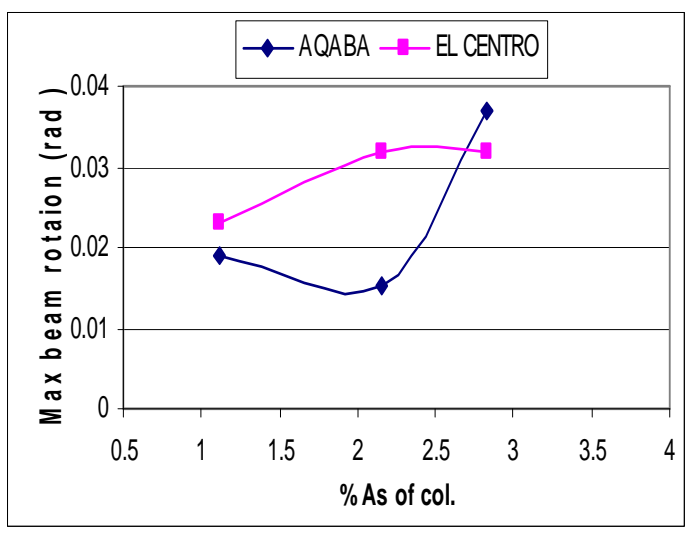

Fig.19: Max. Beam hinge rotation

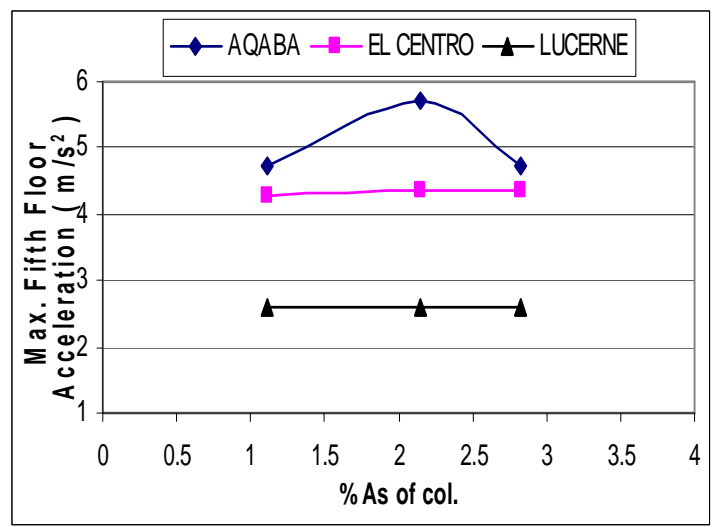

Fig.21: Max. $5^{\text {th }}$ floor acceleration 
The total number of plastic hinges were noticed although this number is always less than the beam plastic hinges number. On increasing $\%$ As col with about $100 \%$ from $1.11 \%$ to $2.15 \%$ this number decreased with $80 \%$ according to El-Centro while still unchanged with respect to Aqaba. When the $\% \mathrm{As}_{\text {col }}$ reached $2.83 \%$ the column hinge formulation was completely suppressed as seen in Fig.22. Both peak floor acceleration and the maximum induced base shear showed no clear relation with increasing $\% \mathrm{As}_{\mathrm{col}}$ as plotted in Fig.20 and 21 resp. except for Al-Aqaba at \% $\mathrm{As}_{\mathrm{col}}$ of $2.15 \%$ which show maximum responses.

On studying the five-storey reinforced concrete frame inter- storey drifts due to increasing the $\% \mathrm{As}_{\mathrm{col}}$, it was found that there is no obvious percentage of column reinforcement to achieve minimum drifts as shown in Fig.24 and 25.

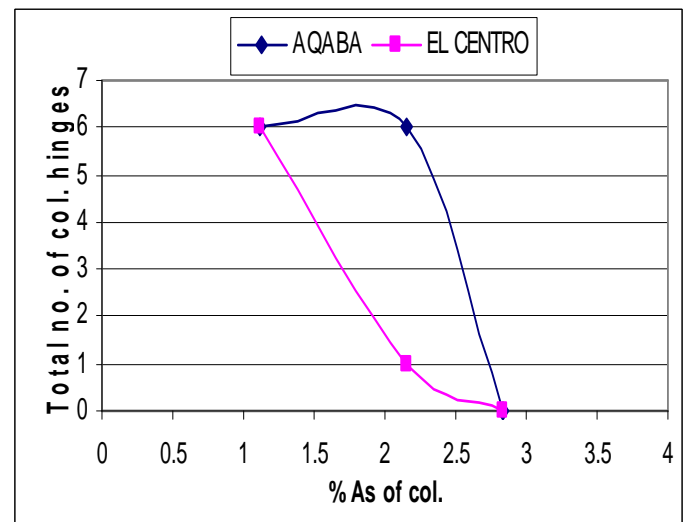

Fig.22: Total number of column hinges

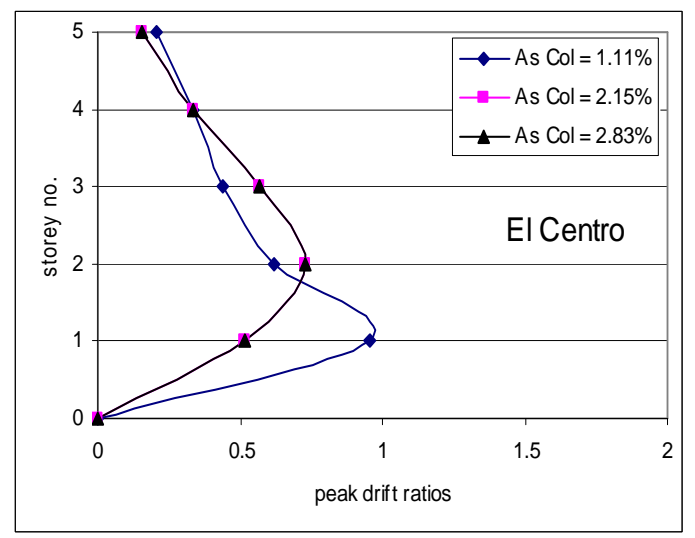

Fig.24: Inter-story drifts due to El-Centro

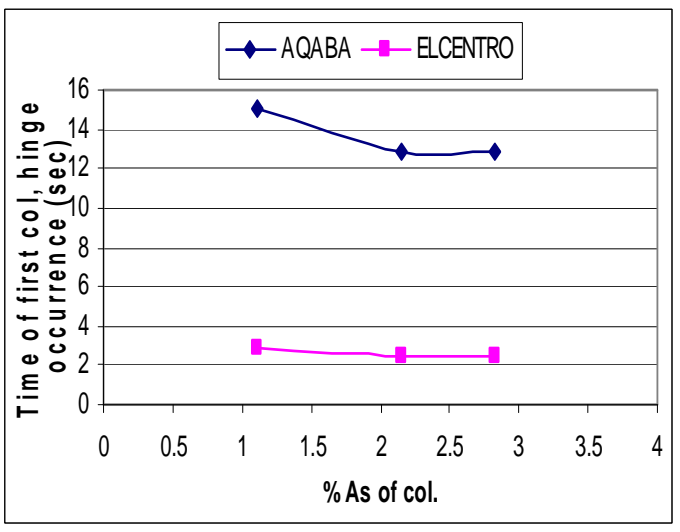

Fig.23: Time of first column hinge occurrence

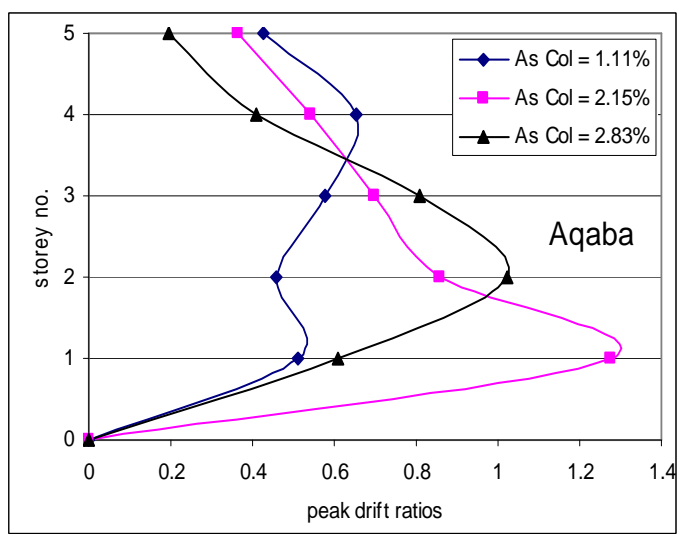

Fig.25: Inter-story drifts due to Al-Aqaba

\section{Second case: Ten story R.C. frame}

- Beam longitudinal reinforcement effect: The results show that the angle of plastic rotation is affected by the ratio of longitudinal reinforcement where on increasing \% As beam with $55 \%$ the rotation is decreased with ratios varying from $25 \%$ to $50 \%$ according to the seismic wave nature and reach its minimum value at $\% \mathrm{As}_{\text {beam }}$ equal $0.53 \%$ as illustrated in Fig.31. Similar to five-storey frame the time of first beam 
hinge was not increased significantly with increasing the $\% \mathrm{As}_{\text {beam. }}$ There was no clear $\%$ As beam that may lead to decrease peak horizontal displacement as shown in Fig.26 for El-Centro and Al-Aqaba.

Similar to five-story frame; increasing the longitudinal reinforcement ratio of beams affects significantly the total number of plastic hinges formed at beam ends, where on duplicating the percentage of beam reinforcement the occurrence of beam plastic hinges directly responds to this increase with reduction ratios vary from $27 \%$ till $36 \%$ but when the $\%$ As beam is increased with 55\% the total number of plastic hinges only decreased by $13 \%$ as illustrated in Fig.29.
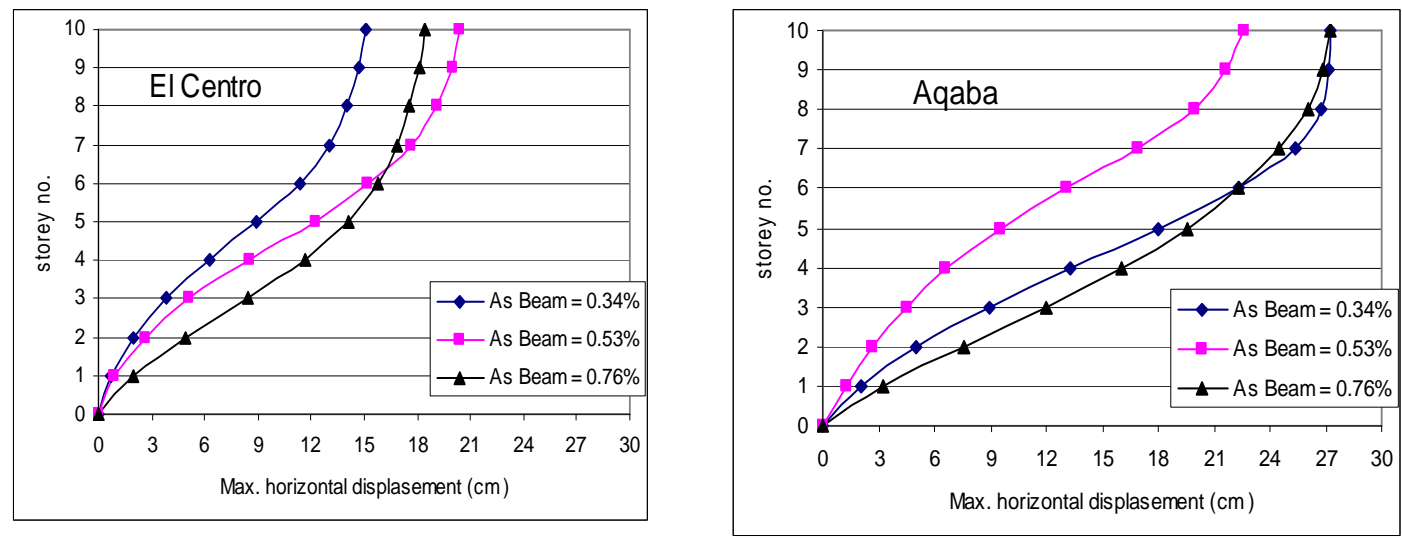

Fig.26:Hz. displacement profile due to El-Centro and Al-Aqaba earthquakes at moment of maximum tip displacement

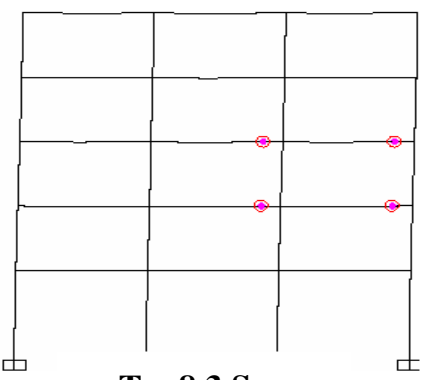

$\mathbf{T}=\mathbf{8 . 3}$ Sec.

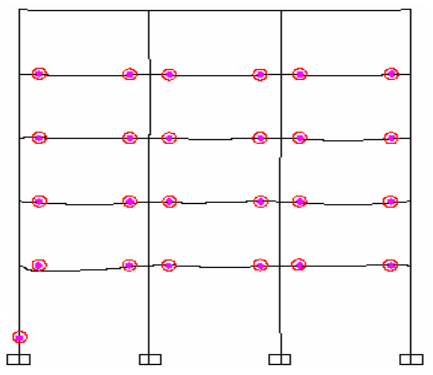

$\mathbf{T}=15.9$ Sec.

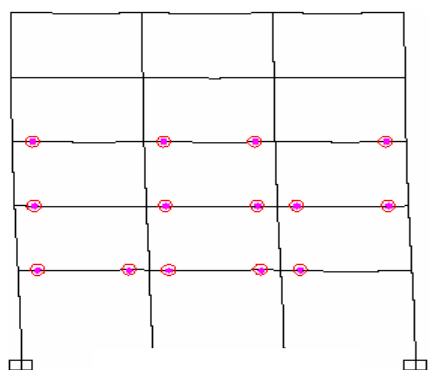

$\mathbf{T}=12$ Sec.

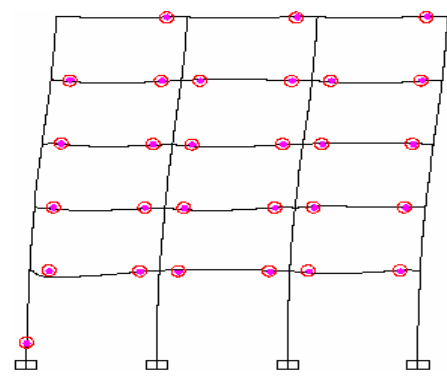

$\mathrm{T}=16.8$ Sec

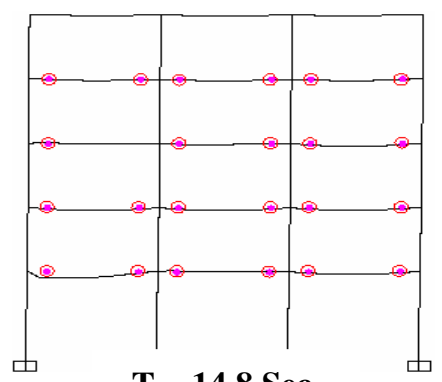

$\mathrm{T}=14.8$ Sec.

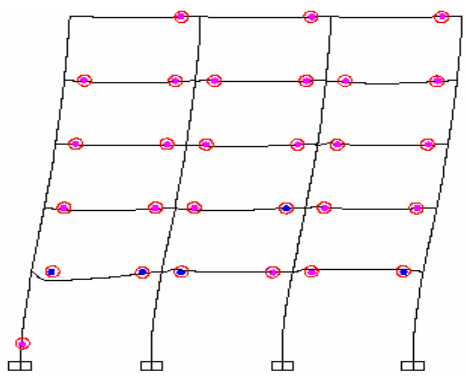

$\mathbf{T}=\mathbf{1 8 . 1 \text { Sec }}$.

Fig.27: Plastic hinges sequence due to Al -Aqaba earthquake in frame No.1 (5 -story case) 

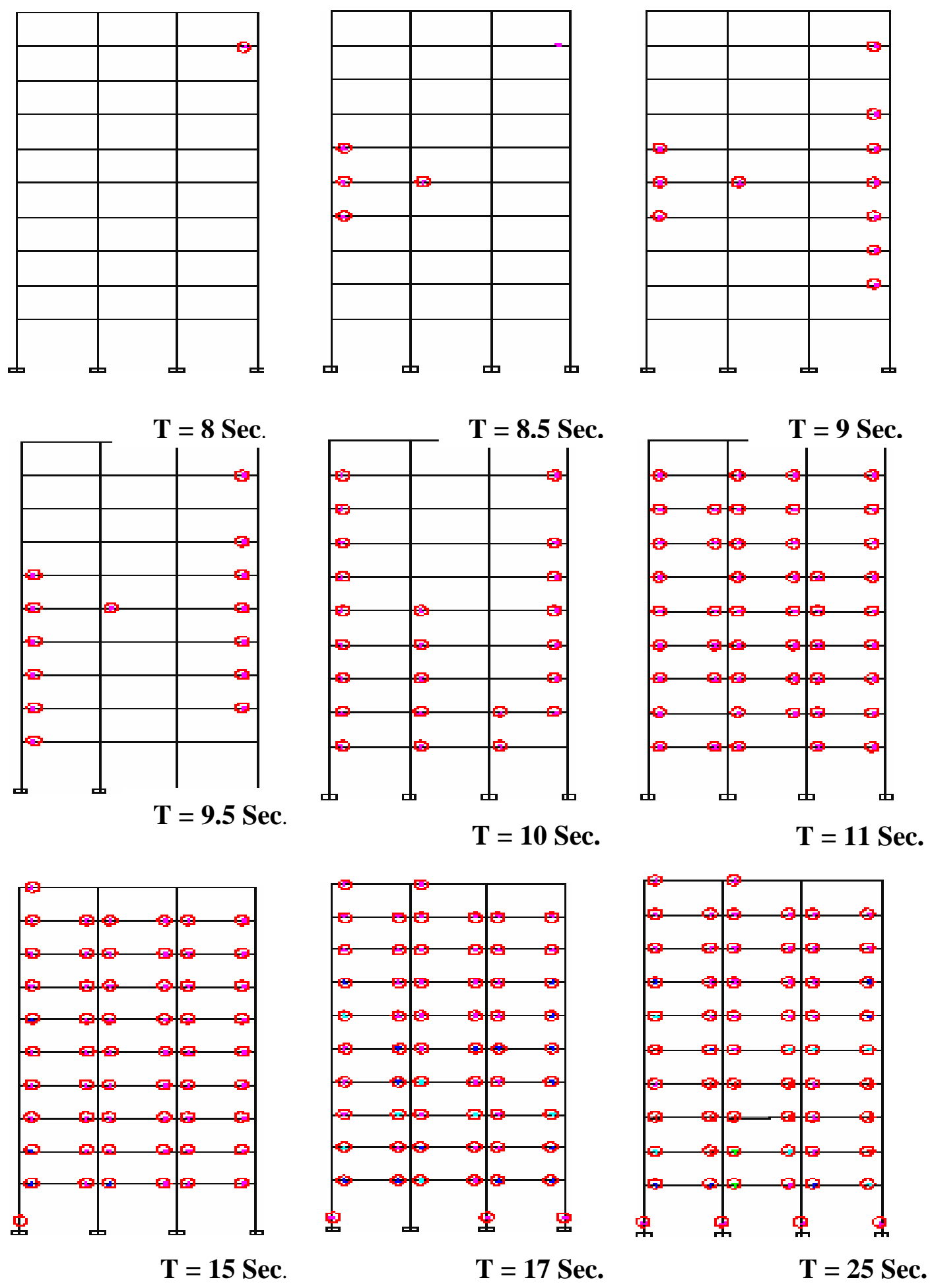

Fig.28: Plastic hinges sequence due to $\mathrm{Al}$-Aqaba earthquake in frame no.1 (10-story case) 


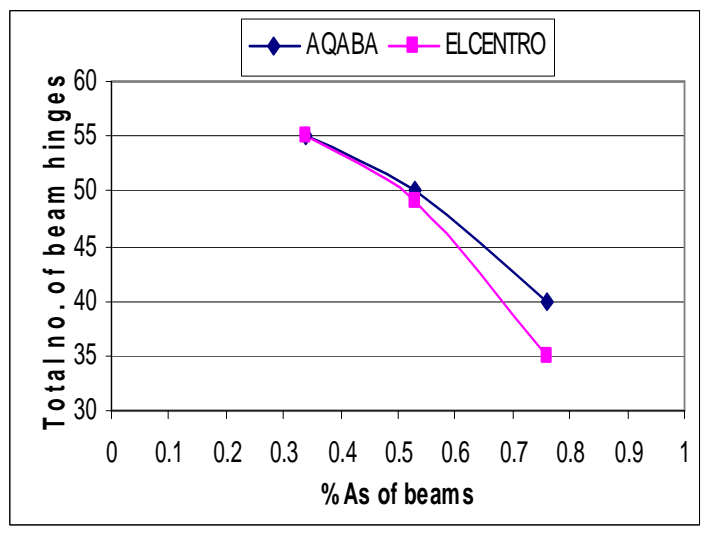

Fig.29: Total number of beam hinges

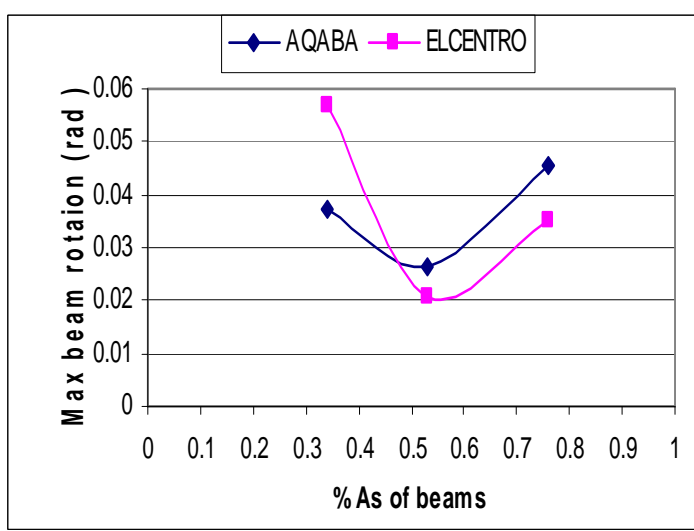

Fig.31: Max. Beam hinge rotation

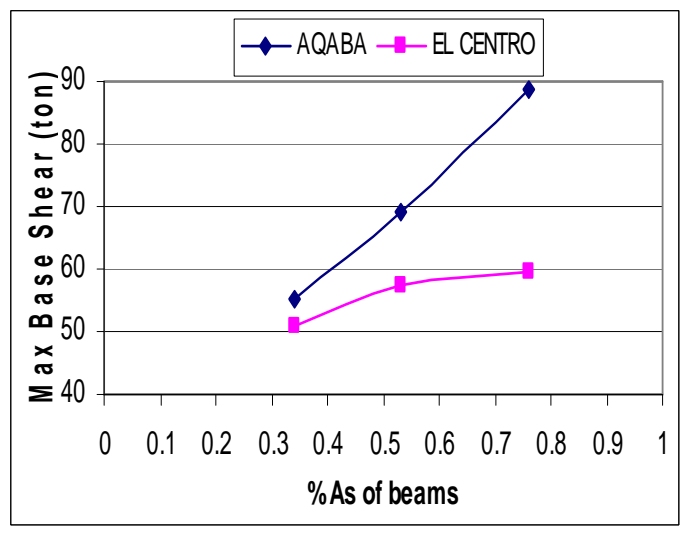

Fig.30: Max. Induced base shear

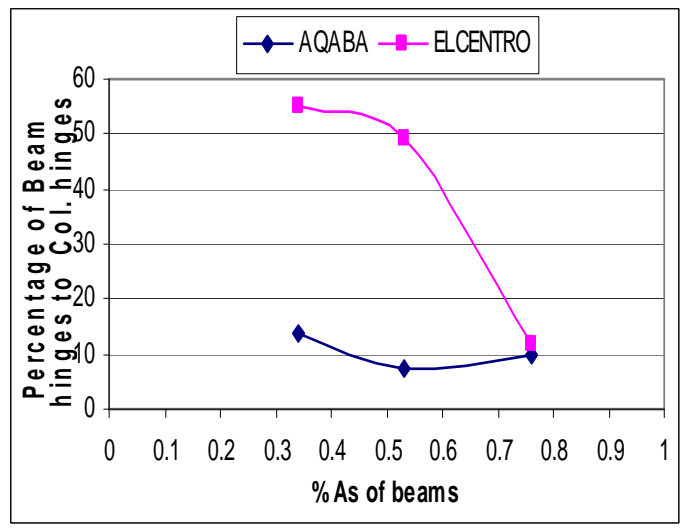

Fig.32: Percentage of beam hinge to col. hinge

The maximum induced base shear showed an increase with different ratios (according to the earthquake nature) on increasing beam longitudinal reinforcement ratio as shown in Fig.30. Taking the plastic hinges formed at column ends on consideration through the ratio of beam plastic hinges number to column plastic hinges number at different earthquake excitations as in Fig.32; it was found that this ratio is decreased by $30 \%-80 \%$ by duplicating the $\%$ As beam which indicates a low number of column plastic hinges formation.

Since it was important to notice the relative horizontal acceleration of floors to evaluate their shaking degree and the influence of changing the $\% \mathrm{As}$ beam on the acceleration value, it has been noticed that the lowest acceleration values were attained at the minimum beam longitudinal reinforcement ratio as seen in Fig.33. The interstory drifts due to Al-Aqaba were plotted in Fig.37 illustrating no clear effect.

- Column longitudinal reinforcement effect: The results show that the angle of plastic rotation is affected by the column longitudinal reinforcement ratio in different manners where on increasing $\% \mathrm{As}_{\text {col }}$ with $100 \%$ the column rotation vanishes and on increasing $\%$ As col with 50\% the column rotation decreased with about 50\% 
according to the seismic wave nature. It should be mentioned that the total number of column plastic hinges was also influenced with increasing $\% \mathrm{As}_{\text {col }}$ and that no hinges were formed at $\% \mathrm{As}_{\text {col }}$ equals $2.15 \%$ as shown in Fig. 34 and 35 respectively. The displacement profile due to Al-Aqaba was plotted in Fig. 36 showing no clear relationship with the $\% \mathrm{As}_{\mathrm{col}}$.

The inter-story drifts due to different $\% \mathrm{As}_{\text {col }}$ were plotted in Fig.37 showing that the maximum drifts were minimum due to column longitudinal reinforcement ratio.
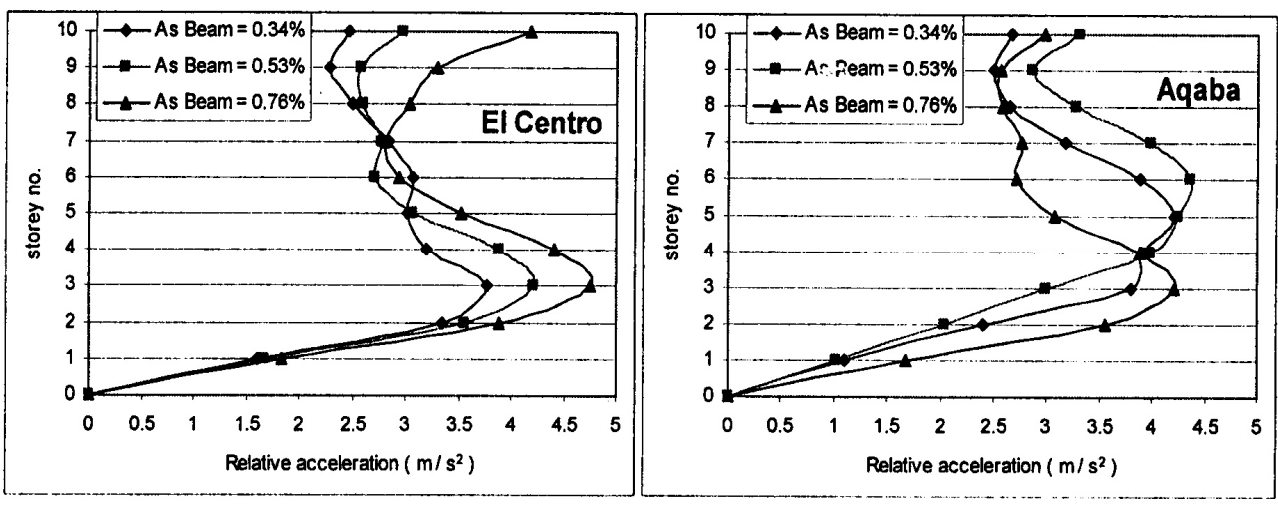

Fig. 33: Relative HZ. Acceleration profile due to El-Centro and Al-Aqaba earthquake

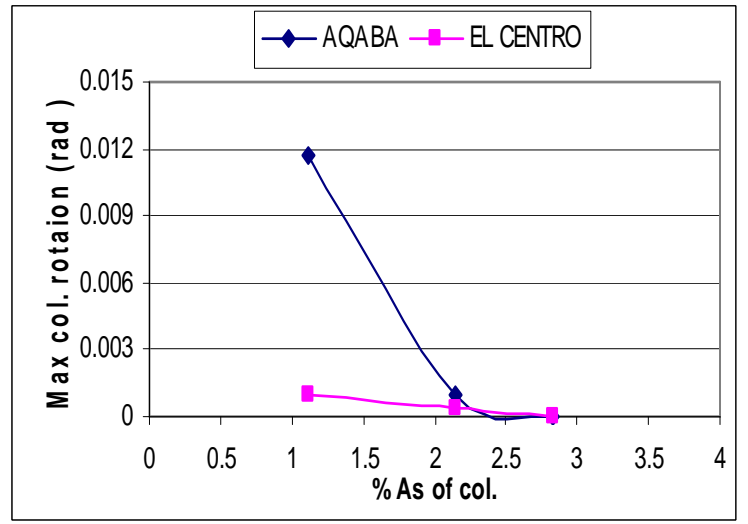

Fig.34: Max. Column hinge rotation

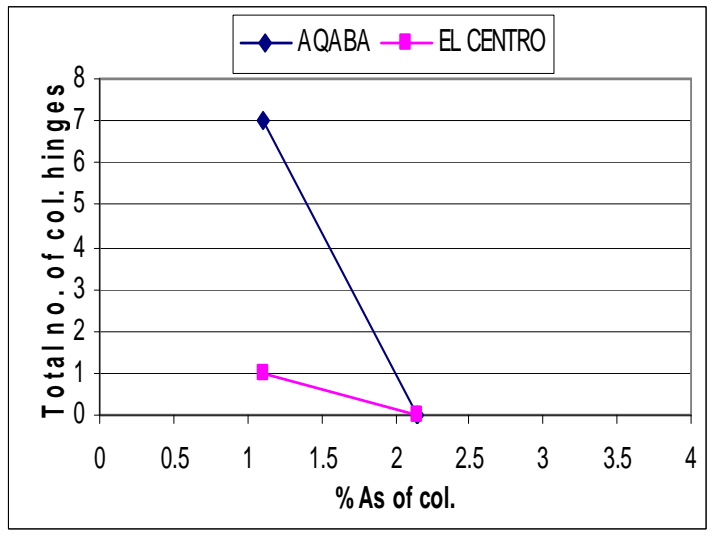

Fig.35: Total number of column hinges 


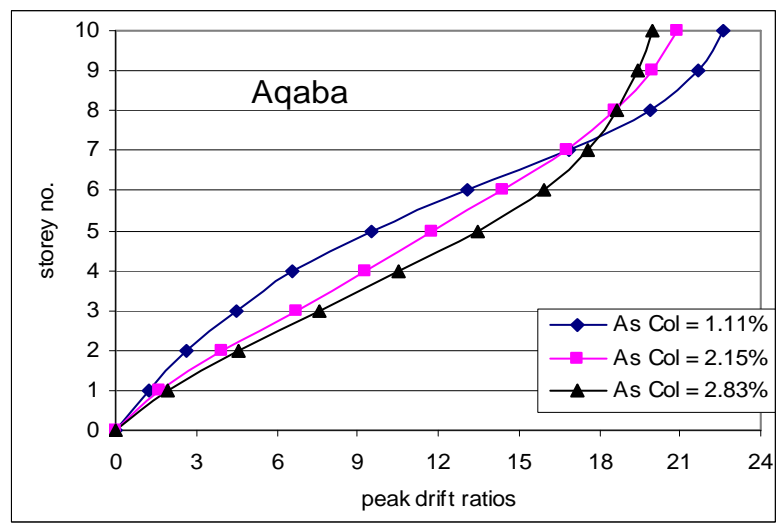

Fig.36:HZ displacement profile due to Al-Aqaba earthquakes at moment of maximum tip displacement
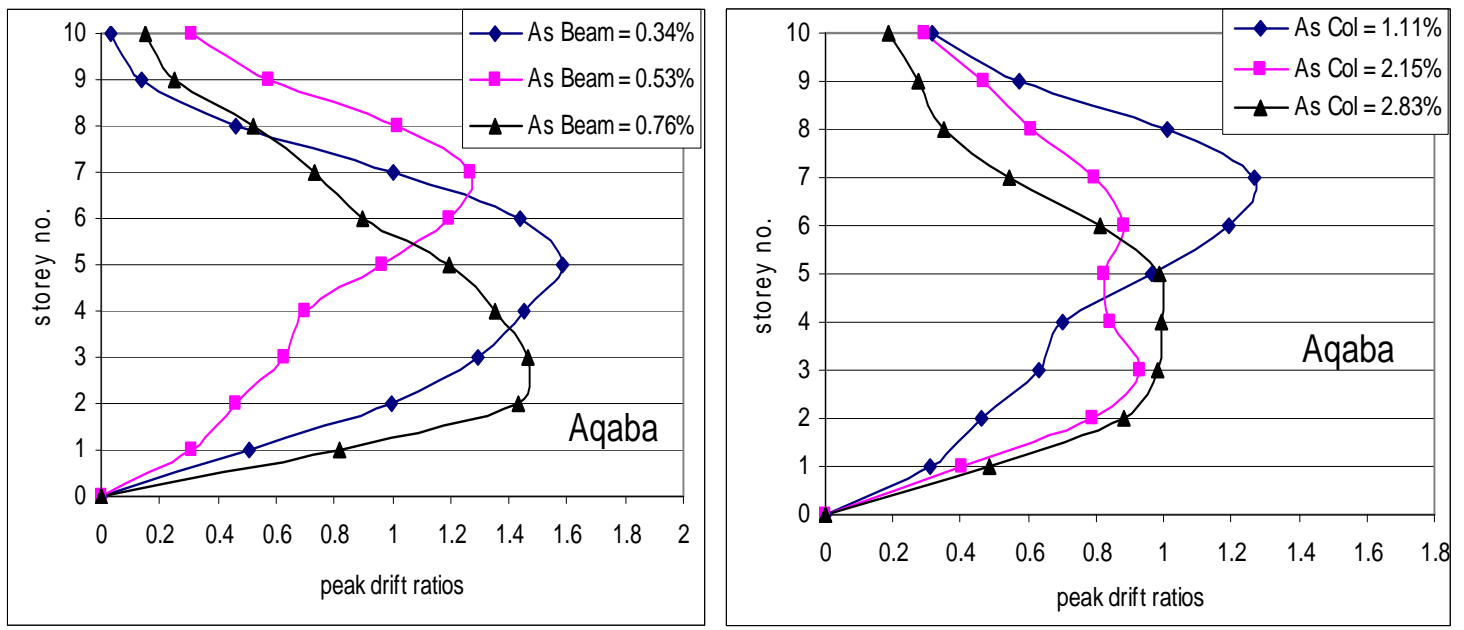

Fig.37:Inter-story drifts due to varying of $\% \mathrm{As}_{\text {beam }}$ and $\% \mathrm{As}_{\text {col }}$ (Al-Aqaba)

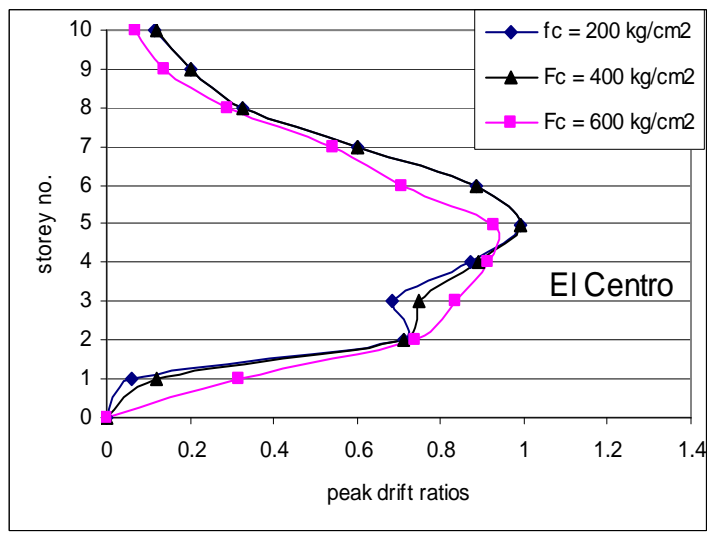

Fig.38 Inter-storey drifts due to changing grade of conc. ( 10-storey frame)

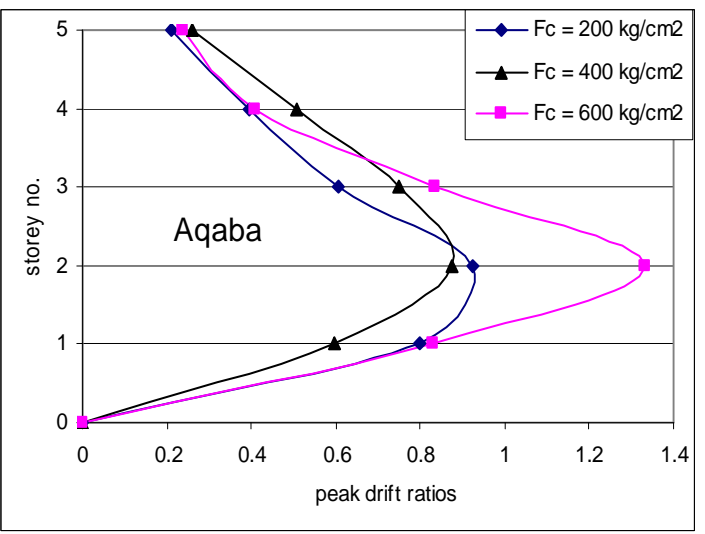

Fig.39 Inter-storey drifts due to changing grade of conc. (5-storey frame) 


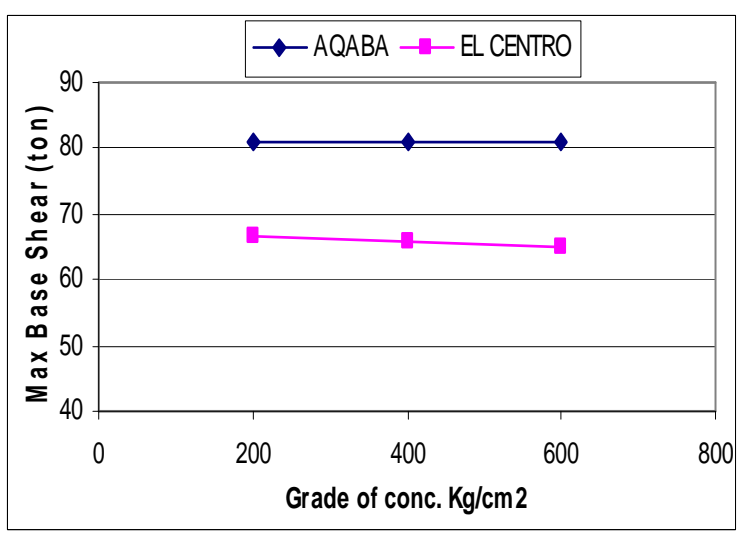

Fig.40 Max. Base shear (10-stories frame)

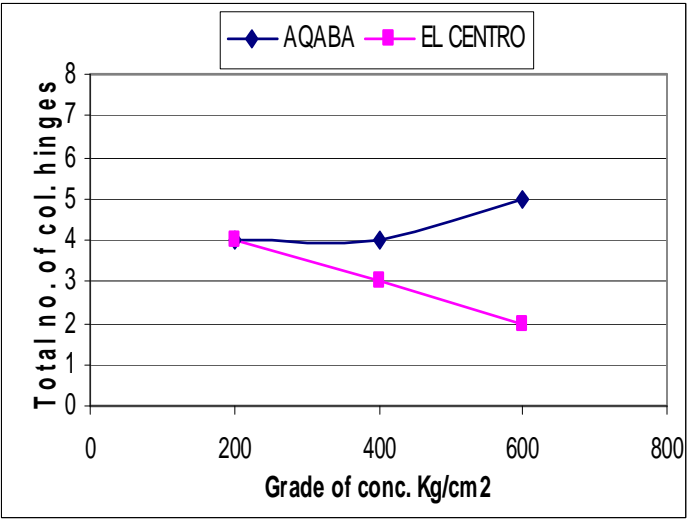

Fig.41 Total number of column hinges (5-story frame)

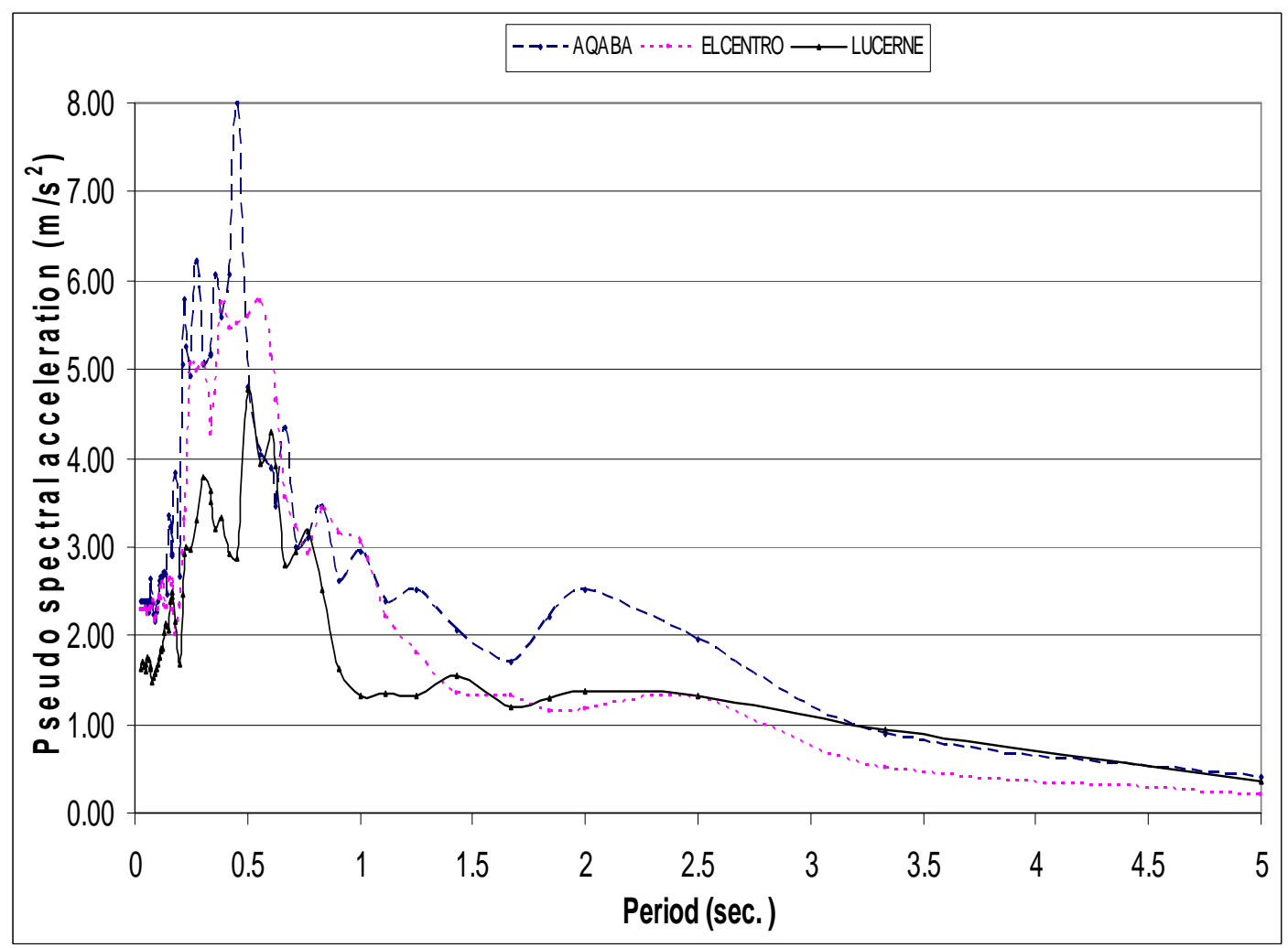

Fig.42 Spectral accelerations of the three used earthquakes 
Column concrete grade: on increasing frame number of stories the normal forces in columns is increased causing column cross-sections to be larger. Figs. 38 and 40 reflect steady inter-storey drifts and maximum base shear of the 10-stories frame respectively while Fig. 39 and 41 show slight effect of the $600 \mathrm{~kg} / \mathrm{cm}^{2}$ grade of concrete on the inter-storey drifts and total number of column hinges respectively, so the overall seismic response of both frames did not show significant effect on increasing the column concrete grade till $600 \mathrm{~kg} / \mathrm{cm}^{2}$

\section{Earthquake Nature Effect:}

As shown in Fig.42 both Al-Aqaba and El-Centro have higher values of pseudo spectral acceleration than Lucerne reflecting the lower response values of the frames subjected to that earthquake wave (in spite of scaling their PGA to 0.25G). As illustrated in the former results of Fig.11, 13, 14, 16, 17 and 21, Lucerne gives the lowest values of maximum horizontal displacement, inter-story drifts, induced base shear and peak floor relative acceleration.

\section{Plastic hinge}

The plastic hinge in a flexural member is a point (in fact it is a zone) on the longitudinal member axis, where the value of the bending moment equals to the plastic moment and where the discontinuity of first derivative of the deflection line (curvature) exists. For reinforced concrete (RC) members, this curvature depends on the tensile strain of the reinforcement and the compressive strain of the concrete. As concrete is a brittle material with little ductility, RC members achieve ductility and adequate deformation capacity mainly through the tensile straining or yielding of the reinforcement. When the tensile strain of the reinforcement is limited, such as in the case of over-reinforced RC beams and RC columns with large axial loads, whereby the tensile reinforcement does not yield and the member fails due to concrete crushing accompanied by buckling of compression steel, the ductility of the member is limited .

\section{7- CONCLUSIONS}

From nonlinear finite element analysis of the seismic behavior of multistory RC frames, the following conclusions were drawn out:

1- The propagation of plastic hinges is obtained. The plastic hinge is assumed to occur when steel reaches yielding or concrete reaches ultimate strength. In all cases, yielding of steel occurs first because the sections are designed to be underreinforced sections

2. Beam hinge rotation capacity decreases with a significant degree by increasing percentages of beam reinforcement ratio in both cases of multi-story RC frames.

3. Total number of column hinges and its rotation capacity are reduced with increasing percentages of column reinforcement ratio where the reduction degree is higher in 5-storey frame than that in 10-storey frame.

4. Increasing the longitudinal reinforcement ratio of beams decreases significantly the total number of beam plastic hinges formed at their ends while the time of first 
beam hinge formation shows little retardation.

5. From studying both of maximum horizontal displacement and inter-storey drifts in the two cases, it was difficult to determine certain beam reinforcement ratio or column reinforcement ratio that lead to a general case of minimum drifts.

6. It has been noticed that the lowest acceleration values were attained at the minimum beam longitudinal reinforcement ratio but it needs to be investigated for more earthquakes with different response spectra.

7. Maximum induced base shear in both frames increased clearly with increasing of the $\% \mathrm{As}_{\text {beam }}$ while showed no clear relation on varying the $\% \mathrm{As}_{\mathrm{col}}$.

8. Using high grades of concrete for columns did not show any noticeable effect on the overall seismic response of frames.

9- In the current study, two motions were considered but they are not enough to judge accurately the effect of input motion characteristics on the inelastic response. An extension of the study is needed for this point.

\section{REFERENCES}

1. Oguzhan Bayrak Sidney and Shamim A. Sheikh : "Plastic Hinge Analysis", Journal of Structural Engineering,September 2001.

2. Sameh S. Mehanny and Gregory G. Deierlein "Seismic Damage and Collapse Assessment of Composite Moment Frames" Journal of Structural Engineering, September 2001.

3. Giuseppe Oliveto and Massimo Marletta :"Seismic Retrofitting of Reinforced Concrete Buildings using Traditional and Innovative Techniques", ISET Journal of Earthquake Technology, Paper No. 454, Vol. 42, No. 2-3, pp. 21-46, JuneSeptember 2005 .

4. American Concrete Institute, ACI Committee 318 "Building code requirements for reinforced concrete (ACI 318-02)", Detroit, 2002.

5. Oguzhan Bayrak Sidney a. Guralnick and Abbes Yala "Plastic Collapse, Incremental Collapse, and Shakedown of Reinforced Concrete Structures" ACI Structural Journal March-April 1998.

6. Marc Gerin, and Perry Adebar ,"Accounting for Shear in Seismic Analysis of Concrete Structures" ,13th World Conference on Earthquake Engineering ,Vancouver, B.C., Canada , ,Paper No. 1747, August, 2004.

7. S. Pampanin, G.M. Calvi and M. Moratti ,"Seismic Behavior of R.C. BeamColumn Joints Designed For Gravity Loads ",12th European Conference on Earthquake Engineering, Paper Reference 726 ,2002.

8. Intel Mehmet and Ozmen Hayri Baytan : "Effects of plastic hinge properties in nonlinear analysis of reinforced concrete buildings " , Journal of Engineering structures, ISSN 0141-0296, Vol. 28, No.11, PP. 1494 -1502, 2006.

9. Khairy Hassan A.: "Analytical Study on Seismic Resistant Characteristics of RC Piers" D.Eng., dissertation to Saitama University, March 1999.

10. Paul S. Baglin and Richard H. Scott "Finite Element Modeling of Reinforced Concrete Beam-Column Connections" ACI Structural Journal, NovemberDecember 2000 
11. Kutay Orakcal, Leonardo M. Massone, and John W. Wallace:" Analytical Modeling of Reinforced Concrete Walls for Predicting Flexural and Coupled Shear-Flexural Responses", PEER , October 2006.

12. A.Kadid and A. Boumrkik :" Pushover Analysis of Reinforced Concrete Frame Structures", Asian Journal of Civil Engineering (Building and Housing ), Vol. 9, No. 1 , PP. 75-83, 2008 .

13. Guowei Ma, Hong Hao, Young Lu and Yingxin Zhoa "Distributed Structural Damage Generated by High Frequency Ground Motion." Journal of Structural Engineering, March 2002.

14. M.Elmorsi, M. Reza Kianoush, and W. K. Tso "Nonlinear Analysis of Cyclically Loaded Reinforced Concrete Structure" ACI Structural Journal, NovemberDecember 1998.

15. Egyptian Code of Practice for RC structures design, No.203, 2004.

16. Mander,J.B., Priestly, M.J.; and Park, R., "Theoretical Stress-Strain Model for Confined Concrete " ASCE, Vol. 114, No.8, pp. 1806-1826, 1986.

17. Mander, J.B., M. J. N. Priestley and R. Park, "Observed Stress-Strain Behavior of Confined Concrete," Journal of Structural Engineering, ASCE, Vol. 114, No. 8, pp. 1827-1849, August 1988 .

18. Sharma, U., Bhargava, P., and Kaushik, S.K.," Comparative Study of Confinement Models for High-Strength Concrete Columns", Magazine of Concrete Research, No. 4, pp.185-197, 2005.

19. W.F.Chen and E.M.Lui : "Earthquake engineering for structural design " U.S.A., 2006.

20. CSI, SAP 2000, Ver. 10.07, integrated finite element analysis and design of structures basic analysis reference manual. Berkeley (CA, USA): Computers and Structures INC; 2006.

21. M. Srikanth, G. Rajesh Kumar and S. Giri : "Moment Curvature of Reinforced Concrete Beams Using Various Confinement Models and Experimental Validation" ,Asian Journal of Civil Engineering (Building and Housing ), Vol. 8, No. 3 , PP. 247-265, 2007.

\section{دراسة نظرية في شكل الانهيار والسلوك الإنشائي للأطر الخراسانية المسلحة متعددة الطوابق والمعرضة لأحمال زلازل الإط الإل}

في هذا البحث تم استخدام نظريـة العناصر المحددة اللاخطية لدر اسـة السلوك الإنشـائي وشكل الانهيار

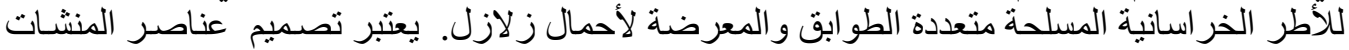

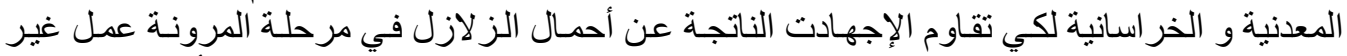

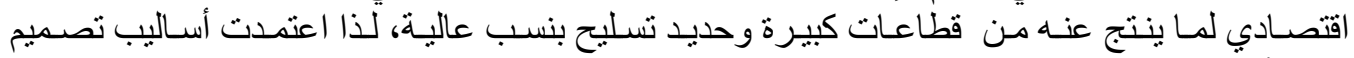

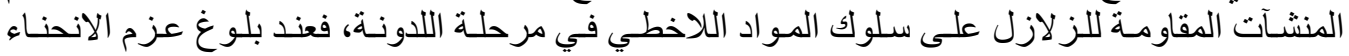

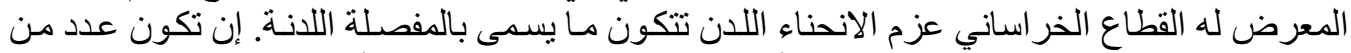

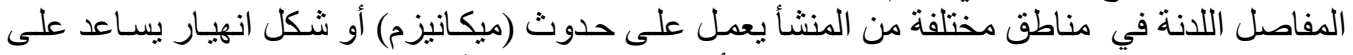

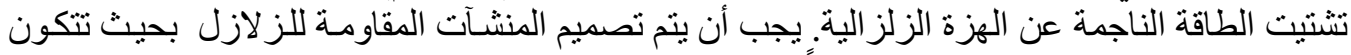

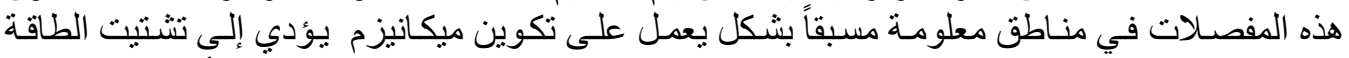

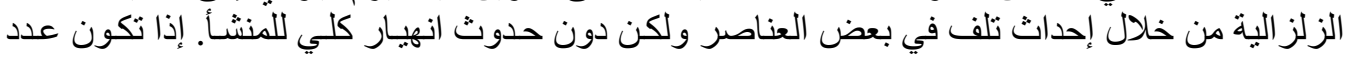


محدد من المفصـات اللدنة في الإطـار بحيث يحدث انهيار يسمى هذا ميكانزم انهيار أو شكل انهيار

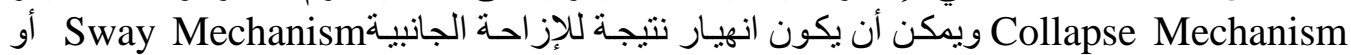

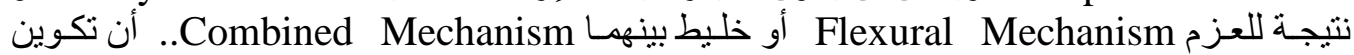
المفصلة اللدنة يحدث عند وصول حديد التسليح الرئيسي للخضوع او او أن الخرسانة تصل لأقصى إجهاد، ألخان.

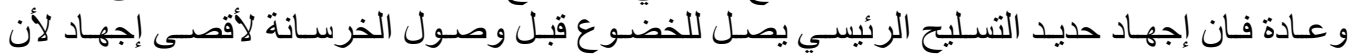

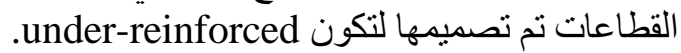

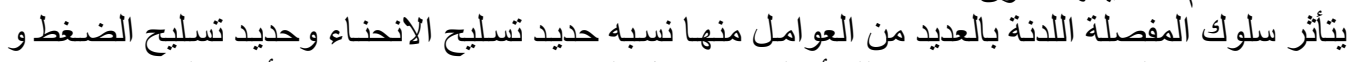

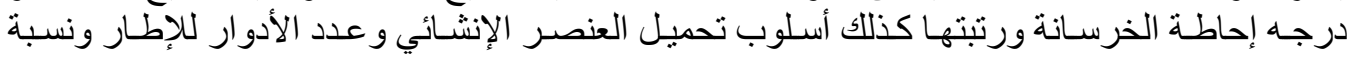

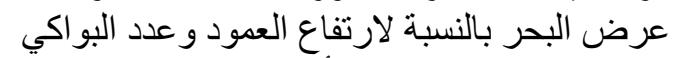

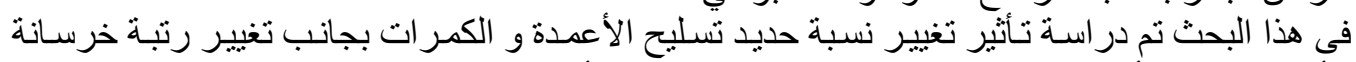

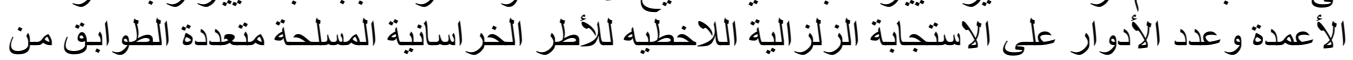

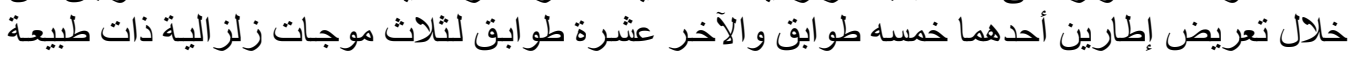

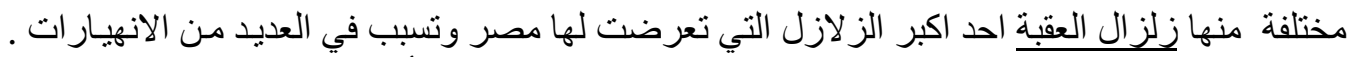

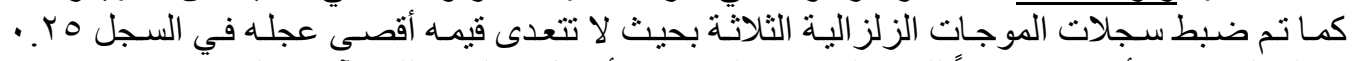

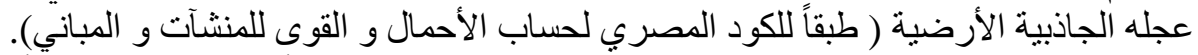

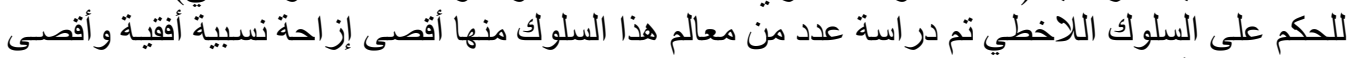

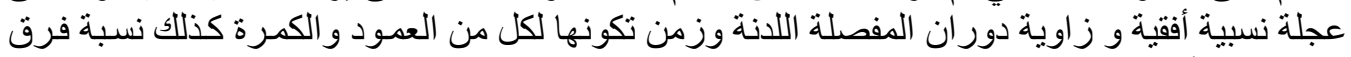

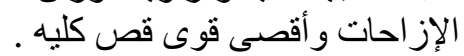

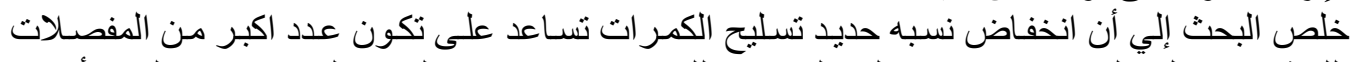

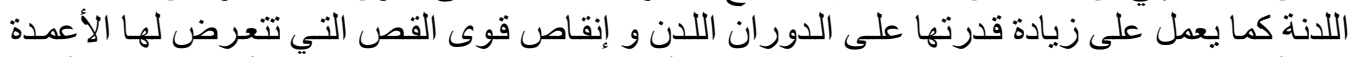

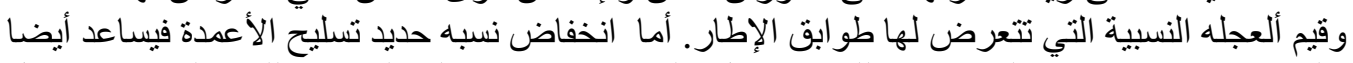

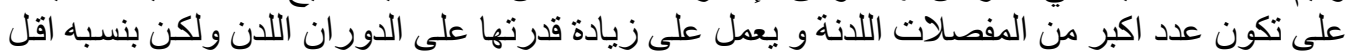

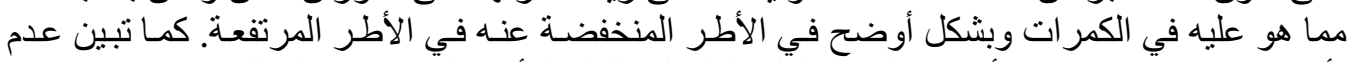
تأثير زيادة رتبه خرسانة الأعمدة على السلوك الزئ الزلز الي الكلي للأطر الخر اسانية المسلحة.

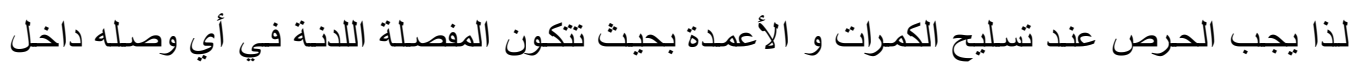

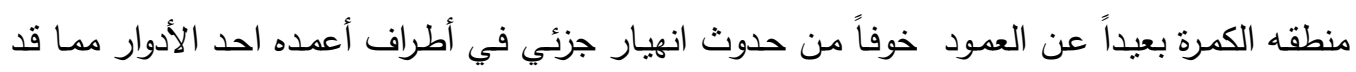

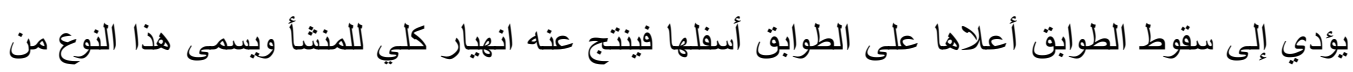
Sandwich Collapse الانهيار 